\title{
A Concept of Eurasia
}

\author{
by Chris Hann
}

To imagine Europe and Asia as constituting equivalent "continents" has long been recognized as the ethnocentric cornerstone of a Western, or Euro-American, world view. The amalgam Eurasia corrects this bias by highlighting the intensifying interconnectedness of the entire landmass in recent millennia. This article builds on the work of Jack Goody and others to analyze the unity-in-civilizational-diversity of the Old World. It draws on the substantivist economic anthropology of Karl Polanyi to postulate continuities between ancient ideals of economic embeddedness in the agrarian empires and various forms of socialism in the twentieth century. Today, when the human economy everywhere is again exposed to the domination of the market, the Eurasian dialectic has universal relevance. However, recognition and realization of pan-Eurasian affinities continues to be impeded by geopolitics, and sociocultural anthropology has a long way to go to overcome its Atlantic bias.

\section{Introduction: Words and Things}

Like other social scientists, social and cultural anthropologists (hereafter "sociocultural" - the differences between these strands are unimportant for this article) have to reflect carefully on their concepts. It is essential to distinguish between the local (emic) concepts of the people studied and the external (etic) concepts of an investigating anthropologist. Adapting a word of the investigator's mother tongue for the purpose of comparative analysis is fraught with danger. Perhaps other languages offer more suitable words and draw their own emic/ etic distinctions in different ways? The history and theory of sociocultural anthropology would be very different if this discipline had developed in a non-European language. It is hard even to imagine what such an anthropology would look like.

This article proposes no new solutions to perennial conundrums. In practice, sociocultural anthropologists are condemned to work within their evolved intellectual communities. We are more prone than most to doubt translatability, but even those who question concepts radically can hardly avoid engaging with the usage established by their predecessors. We generally do so in a spirit of nominalism: the meanings of $X$ are not given in the world, independent of human intervention, but constructed by human agents through acts of naming. Rather than debating universals with philosophers, the job of anthropologists is then to track the social lives of concepts.

Eurasia is a concept of this kind, with a history that can be tracked. However, it is also a spatiotemporalization with a reference in materialist realism, a thing. Eurasia refers to mat-

Chris Hann is a founding Director of the Max Planck Institute for Social Anthropology (PO Box 1103 51, 06017 Halle/Saale, Germany [hann@eth.mpg.de]). This paper was submitted 22 X 14, accepted 24 I 15, and electronically published 19 I 16. ter that has existed in the world for a very long time, irrespective of how we choose to signify it. The precise boundaries of land and ocean have changed, but I am not concerned with geological time frames and only very indirectly with environmental changes. ${ }^{1}$ My aim is to derive a serviceable concept of Eurasia for sociocultural anthropologists from broad swathes of historical and social-science research concerned with grasping concrete processes of change in human society over the past three millennia. My concept is not a timeless "analytic" definition but an "optic" that offers a dynamic perspective on the history of the discipline as well as world history. An additional twist is that, quite recently, the word "Eurasia" has become prominent in public discourse outside the academy. This usage is at odds with my concept, but such is its mediatized influence that the view we now take of this wordconcept may have a bearing on the further evolution of the thing, and, as I argue below, with as little pathos as possible, the planet.

Eurasia, as I use the word (building on many previous contributions noted in the next section), is composed primarily of the landmass that is conventionally divided into the two continents of Asia and Europe (Hann 2006, 2012). As is well known, these names were bestowed by the Ancient Greeks. The conceit in regarding them as equivalent continents, western and eastern, has long been recognized. To insist on "Eurasia" is thus to correct an ancient bias. The compound draws attention to the constructed character of the terms "Europe" and "Asia." It prompts reflection on the arbitrariness of many

1. Thus, I do not engage with "deep history" or even with the popular theories of Jared Diamond (1997), who explains the history of Eurasia, over time frames significantly longer than mine, in terms of its basic contours, notably the vast east-west extent of temperate climatic zones.

(C) 2016 by The Wenner-Gren Foundation for Anthropological Research. All rights reserved. 0011-3204/2016/5701-0001\$10.00. DOI:10.1086/684625 
other classifications (such as the West's imposition of "Orient" on a Chinese society that has traditionally considered itself to be the Middle Kingdom), on the very concept of a continent, and on the ideological implications of such "metageography" (Lewis and Wigen 1997).

But of course Eurasia, too, is necessarily a construction. This amalgam is a product of relatively recent scholarship. ${ }^{2}$ It is certainly not an emic term, not a collective identity professed by particular populations of humans (except in parts of Southeast Asia-see “'Eurasian' in Biological Anthropology" in the appendix). To which territories and populations shall we apply it? The landmass (i.e., Europe + Asia) is the most obvious presumption. A case could be made, however, for using it to designate a zone at the interface. Precisely because there are no clear physical boundaries between the continents as they were conceived by the Ancient Greeks, the scope of this interface-Eurasia is rather vague, though evidently smaller than the "entire-landmass" presumption. Clearly, this or any other subset usage would offer an entirely different optic. From initial nominalist principles (the principles of Humpty Dumpty), it would be just as valid to proceed in this way. Nowadays it has to be recognized that, in the Englishspeaking world, "Eurasia" is increasingly invoked as the collective label for a limited number of post-Soviet states (there is no consensus as to the exact number), with the possible addition of Mongolia. I argue that such narrow definitions are unfortunate from the perspective of historical social realism, partly because they have become clouded by contemporary political ideologies. I return to this point in the final section.

Having conceded that the word "Eurasia" has contingent origins and that it has not been used in a consistent way by scholars, I nonetheless assert that it remains the best term available to denote the largest landmass of the planet, including large islands such as Great Britain and Japan. However, my concept of Eurasia is not determined by geographical, geological, or other boundaries set by nature. To this geographical landmass I add the southern shores of the Mediterranean, in other words, the northern zones of the continent known as Africa. In the epoch during which the key features of this historical Eurasia emerged, from roughly 1000 BC, civilizational interconnectedness intensified across the Indian Ocean as well as overland via what has recently been termed the Silk Road. Most sub-Saharan populations, together with many in the landmass itself, especially in its vast northern regions, were not integrated into this connectivity for a very long time. Eurasia included not just the agrarian empires but also the pastoral nomads of the "Near East" and "Inner Asia." In some historical eras, the nomads were instrumental in bringing very large territories under one polity. However, my use of Eurasia is not dependent on the fluctuating extent to which

2. Wiederkehr (n.d.) traces the nominal form to the Austrian geologist Eduard Suess, in 1885. The adjectival form was already common at this time in several European languages. territories of Europe were politically united with territories of Asia (very considerable under Genghis Khan and again later under the Russian Empire and under Marxist-Leninist-Maoist socialism). Eurasia is simply the name for a "supracontinental" unity forged over the past three millennia. This Eurasia expanded from its core civilizations to include more and more nonagrarian penumbra regions, where quite different forms of civilization developed. ${ }^{3}$ Recognition of Eurasia is no impediment to supplementary spatial, temporal, and sociocultural categorizations within the larger entity.

This unity must not be exaggerated. Its beginnings are particularly obscure. New forms of hierarchy emerged in human society during the Neolithic as a result of innovations in the means of production and communication. The mobility of goods, people, and ideas intensified in a dialectical relation with controls over these processes, including persuasive as well as coercive forms of power. To impose any neat periodization on these gradual processes can seem arbitrary, even spurious. I specify the first millennium BCE in order to include the entire Axial Age, with its radical changes in "religious" consciousness in multiple locations of Eurasia, but I do not postulate religious or "cognitive" changes as the drivers. Important developments in political economy can be traced back to earlier millennia. By the beginning of the Common Era we can recognize a tenuous east-west connectivity stretching from the Atlantic to the Pacific. But it took a further two millennia to incorporate the more northerly regions of the Eurasian landmass; this was accomplished in Siberia only when the institutions of Marxist-Leninist-Maoist socialism were imposed in the twentieth century. By this time, global systems had already integrated the entire planet to an unprecedented degree. This globalization has accelerated since the demise of these socialist regimes.

It follows from these preliminary observations that a concept with these spatiotemporal demarcation lines is by no means self-evident, either in nature or in history. The construction requires justification. My arguments are presented in three linked sections. In the first and longest section, I draw on anthropology and adjacent disciplines to review the history of Eurasia between the end of the Bronze Age and the decades that followed the Second World War, commonly known as the Cold War era. Second, I examine the present global conjuncture following the demise of socialism and argue that solutions to urgent dilemmas can be found by building on the historical accomplishments of Eurasia. Third, I consider why anthropology has more difficulty than other disciplines in recognizing Eurasia. I conclude by arguing that to embrace Eurasia in the maximally inclusive sense corrects a long-term bias in the discipline and at the same time gives it a fresh critical edge on the contemporary world.

3. "Civilization" is used here in the Maussian sense of civilisation, a "family of societies," rather than German Zivilisation or Hochkultur (see Schlanger 2006; on the "civilizational dimension," see Arnason 2003). 


\section{Eurasia through Three Millennia}

To track the history of Eurasia as material thing, as distinct from the word, a sociocultural anthropologist is obliged to rely on secondary sources in other disciplines. I follow historian William H. McNeill, who even in his early work devoted to explaining the "rise of the west" dealt with the supercontinent as a whole (McNeill 1963). Marshall Hodgson preferred to designate the same space "Afro-Eurasia" (Hodgson 1974). This is what one would expect from a scholar whose main preoccupation was Islam, the dominant civilization of the southern shores of the Mediterranean. The important point is that Hodgson, like McNeill, disavowed any separation between Europe and Asia as continents. Johann Arnason (2015:486) terms this unity the "Eurasian macro-region." This appears to constitute a mainstream position in contemporary scholarship, whether or not the scholar uses the term "Eurasia” (e.g., Darwin 2007 does so, while Morris 2010 does not). In this sense, Peer Vries (2009:16) has even complained recently of "a certain Eurasia-centrism in current global history."

For the gestation of this supercontinent we need to look first of all to archaeology. One of the first to insist on the interconnectedness of the Eurasian landmass was the Australian Gordon Childe, who emphasized not the emergence of agriculture in the Neolithic, a world-historical process with parallels in Africa and the Americas, but rather the emergence and long-term consolidation of highly stratified societies on the basis of literacy and the new urban economies that flourished in the Bronze Age (Childe 1942). He was strongly influenced by the materialist paradigms of progress of Engels and Marx. Childe's Eurasianist credentials can be questioned in the sense that, while stressing connections across the landmass, he did so from a premise of European exceptionalism that has affinities with what later came to be termed Orientalism. He was convinced that essential differences between East and West could be traced back over millennia (Wengrow 1999). Nonetheless, his work has inspired later prehistorians to document the exchanges of goods and ideas between East and West without such a teleology and even to theorize these movements in terms of "world systems" and globalization (Wilkinson, Sherratt, and Bennet 2011).

Of course, the "world systems" reconstructed by prehistorians on the basis of material culture cover only a small expanse of the territory of the landmass. The steady expansion of the zone of intense connectivity in the "Near East" can be illustrated in the distribution of sealings (cretulae) from the seventh millennium BC onward. If sealings and weights are key indicators of "control mechanisms. . . . fundamental to achieve institutionalized and long-term inequality" (Rahmstorf 2012:311), it seems that new forms of polity were well established by the middle of the third millennium BCE.

In sociocultural anthropology, Jack Goody has consistently acknowledged his debt to Childe in the course of developing his own conception of the unity of Eurasia. Goody's initial insights derived from his ethnographic research in West
Africa. He contrasted plow agriculture in Eurasia with reliance on the digging stick in sub-Saharan Africa and linked the differences in technology and productive efficiency to differences in kinship, household organization, the holding of property, modes of inheritance, and technologies of communication (Goody 1976, 1977). The agrarian societies of Eurasia spawned vast empires, cities, and social hierarchies marked by enormous differentiation in consumption, which contrasted sharply with almost everything Goody knew from West Africa (Goody 1982, 2006a). Having expounded this intercontinental contrast, Goody focused more in later work on East-West comparisons within the supercontinent. His principal aim has been to critique Eurocentrism via a concept of Eurasia that is based on "alternating leadership" between East and West, mediated by flows of goods and ideas along the established overland and maritime routes. This model of alternation did not break down until the nineteenth century (Goody 1996, 2006b, 2010).

Goody's work in distinguishing Eurasia from social organization south of the Sahara forms the basis of my own concept, but I supplement his account by drawing attention to unity and diversity in the civilizational dimension, which he neglects. One example, central to the dynamics of Eurasia, is the long-term interaction between the sedentary agriculturalists who form his main focus and neighboring populations of pastoral nomads and hunter-gatherers. Here, too, we can speak of vast zones of connectivity dating back many millennia, shaped by environmental change as well as sociocultural factors. However, these pastoralists did not develop radically new forms of society, polity, and cosmology comparable to those of sedentary peoples, and they are thus overlooked by Goody. Together with historians and historical sociologists, anthropologists such as Anatoly Khazanov (1984) and Thomas Barfield (1989) have demonstrated the symbiotic nature of the nomadic frontier, broadly confirming an analysis offered centuries earlier by Ibn Khaldun for Islam in North Africa (Gellner 1981). To focus on exchanges across the EastWest agrarian belt and the maritime routes is inadequate. At the latest from the middle of the first millennium CE onward, an additional key contrast is that between the "inner" and "outer" components of Eurasia (Arnason 2015). ${ }^{4}$

Another weakness in Goody's approach is his treatment of what Johann Arnason terms the "religious-political nexus." The era in which Eurasian agrarian societies consolidated their distinctive historical paths was that characterized by philosopher-historian Karl Jaspers (1948) as the Axial Age, in which new means of communication enabled not only new understandings of what it means to be human but also novel ways to legitimate political power. These ideas have generated productive debates in historical sociology, culmi-

4. Arnason (2015:488) defines "inner Eurasia" as "the whole area between the Siberian Arctic and the shifting borders of settled civilizations in the European, Iranian, Indian and Chinese worlds." The integration of the civilizations of remote forest and tundra regions, notably in Siberia, was of course much weaker. 
nating in theories of "multiple modernities" in which the principal civilizational units are defined by the "world religions" that can be traced back to the Axial Age (Arnason, Eisenstadt, and Wittrock 2005; Eisenstadt 2002). Some scholars are now beginning to question classical formulations of this concept, for example, by expanding it to include the much later religions of Christianity and Islam (Bellah and Joas 2012). Goody has taken little interest in these debates. More generally, he does not address the ways in which the longterm unity of Eurasia is inflected by civilizational pluralism, whether this is defined narrowly with regard to religion or more broadly, inside or outside the agrarian belt. He prefers to focus on the transmission of ideas and technologies across Eurasia via what he calls "merchant cultures" (Goody 2004: $150-154)$. He uses this term in a very broad sense, consistent with archaeologists who emphasize the significance of exchange and commoditization from ancient times (Sherratt and Sherratt 1991). Goody's argument is also consistent with expanding bodies of scholarship that push the origins of capitalist modernity much farther back in time and critique "European miracle" narratives that place undue emphasis on developments in Western Eurasia in the past half-millennium.

Yet merchants were not the only agents in these unprecedented social formations. In Europe before it was named as such, Aristotle emphasized the values of the self-sufficient oikos, the well-ordered estate. In China before its classification as one region of "Asia," Confucius was similarly disparaging of the traders. They existed, they were important, but their prestige was relatively low, and their operations were constrained by the controls of state officials. In the jargon of much later schools of anthropology and economic sociology, the economy was everywhere "embedded" in a sociopolitical whole. Goody pays too little attention to this embeddedness and to its sacred legitimation, which varied from one civilization to the next. ${ }^{5}$ The common characteristics were new notions of community and responsibility, elaborated through ideas of solidarity and even love of one's neighbor. I do not propose these new concepts of morality and "transcendence" as the main drivers of human social evolution in this period, but neither do I dismiss them as mere superstructure or clutter. The key fact is that a succession of Eurasian civilizations developed new combinations of redistribution and exchange, or of state and market, to employ the binary that became dominant much later. They legitimated these structures through ideals of sociopolitical inclusion, including the concept of democracy itself, which clearly differed from the equivalent principles in pre-Axial societies (primarily kinship). That slaves were not members of the polis, and that these societies were more highly stratified than all previous human societies, does

5. Islam might appear to be an exception in that the Prophet was himself a merchant, but here too, as in all the other civilizations, impersonal trade and market motivated by profit were subordinated to other norms of society and polity. not invalidate the significance of this ideological background for the organization of the economy.

When we enter the past 500 years, recognition of Eurasia is occluded in Western scholarship by the extraordinary history of European expansion, primarily via the maritime empires of northwest Europe but also by the Russian overland conquest of most of Central Asia and Siberia. This is the time frame of Eric Wolf's magnum opus (Wolf 1982). Alongside Goody, Wolf is untypical among twentiethcentury anthropologists in the attention he pays to longterm historical factors. In his conceptualization, Europe is not essentially different from "tributary" states at the other end of the landmass. And yet the very title of this work, combined with its limitation to the recent centuries of North Atlantic domination, serves to reinforce the dominant paradigm of European or Western exceptionalism. Much the same can be said of the many anthropological studies influenced by the world-systems theory of Immanuel Wallerstein (1974), which is marked by the same bias toward the Atlantic transformations of the past half-millennium.

Industrial society and its principal container, the nationstate, were born little more than two centuries ago. The extent to which these forms of society were ushered in by the earlier histories of Atlantic imperial expansion remains controversial. What matters for my concept of Eurasia is that, by the end of the eighteenth century, more than three millennia of hierarchical agrarian society were being called radically into question: economically by the rise of manufacturing and radical shifts in the relations between town and country, and politically by the extension of parliamentary democracy and proclamations of universal human rights, epitomized in the French Revolution. The outstanding theoretician of this transition is Karl Polanyi, whose vision extends back to the Axial Age and whose notion of a "great transformation" is more subtle than is commonly recognized (Polanyi 1944). In this magnum opus, Polanyi coupled a materialist account of the politics and economics of the long nineteenth century with close attention to the economic ideology of laissez-faire, which became dominant in this era. When the "self-regulating market" became the dominant "form of integration" of the human economy, understood in a substantivist sense as the meeting of needs, this market principle threatened social peace and led to various forms of reaction in society, some benign (such as the formation of trade unions) and some malignant (such as jingoism and warfare). Sometimes Polanyi and his substantivist followers in economic anthropology referred to this dominance of the market as a "disembedding" of the economy from society. Their critics on this point see "market society" as merely a distinctive form of embedding, since it too depended on specific political and social conditions and usually on an exceptionally strong state, without which these conditions could not be imposed (Block and Somers 2014). Only in the "utopian" terms of liberal ideology can this market society be viewed as free, on the basis of an illusory homo economicus detached from his social context. The challenge, according to Polanyi, writing 
during and after the Second World War, was how to devise new forms of reembedding the economy according to the original Aristotelian prototype, which would enable complex "machine societies" to avoid the horrors of mass unemployment, fascism, and warfare. ${ }^{6}$

In the second half of the twentieth century, this challenge was effectively met in large parts of the world, including virtually the whole of Eurasia. It was met in two distinct ways, both of which reflected the impact of socialist-communist ideas stemming from Karl Marx and Friedrich Engels. The workers' movements often railed against religion and the established churches, casting them as integral components of class-based oppression. In theory, the triumph of communism was to be accompanied by the demise of all such superstition and the triumph of scientific atheism. In practice, implementation was inconsistent, and only Albania ever dared formally to abolish religion. Following the collapse of the Soviet bloc, it has become easier to recognize the long-run continuities between Marxism and the pan-Eurasian heritage of Aristotle and Confucius. ${ }^{7}$ The Marxist-Leninist-Maoist (M-L-M) states that explicitly embraced the doctrines of the nineteenthcentury founders, most of them economically "backward" in comparison with the West, institutionalized a new version of the religious-political nexus. Society was subjected to rigid controls through one-party rule ("the dictatorship of the proletariat”) and central planning. However, although older forms of stratification weakened or disappeared, new inequalities appeared. Although private accumulation was severely constrained, the spirit of homo economicus did not necessarily wither in these conditions, since individuals found themselves obliged to adopt selfish maximizing strategies in response to economic shortages (Verdery 1996). Nonetheless, for all its contradictions, this was the path endorsed by Polanyi himself. In his mature view, this form of socialism represented the only hope in the long run for rescuing humanity from the catastrophes of capitalist market society. ${ }^{8}$

6. This is not the place to expand on the epistemology and history of the substantivist school in economic anthropology, which was most effectively codified by George Dalton after Polanyi's death (see Dalton 1968). Goody is dismissive because of Polanyi's apparent denial that price-forming markets existed in a wide range of preindustrial, precapitalist societies. But the substantivist position can be rescued if one allows "market exchange" to take its place as one form of integration alongside others. Polanyi certainly overstated the absence of market activity in Ancient Greece; but the market did not become the dominant form until the decades after the death of Adam Smith, the political economist most widely invoked both to explain and to justify the new order. See Hann and Hart (2011).

7. In the 1930s, Polanyi had no trouble in squaring his socialism with Christianity; see Dale (2010:39-41).

8. This fervent commitment to socialism did not prevent Polanyi from objecting throughout his career to those elements in the Marxist tradition that to him smacked of economic determinism. See Dale (2010).
However, in the same era, largely coinciding with the Cold War, another "great transformation" was accomplished in the opposing camp, that is, the economically advanced countries of the West. These did not embrace M-L-M socialism, but many of them elected Labour or Social Democratic political parties to power. This "electoral socialism" (Goody 2003) played out very differently from the religious-political nexus of previous millennia, but it was able to harness older notions of society to institutionalize unprecedented welfare states based on universalist principles of inclusive citizenship. The result was by no means identical to that of the "other" bloc, since the mixed, or Keynesian, or "social market," economies of the West allowed much more scope for private accumulation. Nonetheless, the market was no longer so dominant. In the new institutions of "embedded liberalism" (Ruggie 1982), this form of integration was moderated by a strong principle of redistribution, grounded in ideals of solidarity and social harmony. It was also characterized by high standards of protection for what Polanyi (1944) termed the "fictitious commodities" of labor, land, and money.

From such a revisionist Polanyian perspective, the Cold War in Eurasia, commonly represented as a contest between totalitarian central planning on the one hand and liberalindividualist free markets on the other, is thus better seen as a struggle between two variants of socialism, M-L-M and "electoral." The differences between them were significant, but there was great empirical variation within each and many elements of convergence. In the 1960s, reviving the ideals of the New Deal that Polanyi had admired before the Second World War, Lyndon B. Johnson's Great Society program extended citizenship entitlements in the United States. Hungary launched its New Economic Mechanism at almost the same time, decentralizing responsibilities and introducing many more elements of the market to an economy that remained fundamentally socialist in terms of ownership. When I began fieldwork in Hungary in the 1970s, some elements of this "reform socialist" economy seemed strange to me, but many others were thoroughly familiar from my background in Britain, such as the provision of free health care and universal pensions. In certain fields, including student grants, the British variant was more generously redistributive than the Hungarian.

During the Cold War these two variants of Polanyi's great transformation competed furiously for followers all over the planet. The M-L-M variant was propagated in many countries of Old-World Eurasia, including India and Egypt. On the basis of their vast hydrocarbon resources, many other regions of the Islamic world were able to implement their own versions of a socialist agenda, the most quixotic being that of Colonel Gaddafi's Libya (Davis 1987). Soviet socialism was implemented somewhat more conventionally and provocatively in Cuba, although elsewhere in the Americas the United States was eventually able to ensure that Western models predicated on the capitalist mixed economy would prevail. In short, following the disruption of the first century-and-a-half of the industrial era, with all the catastrophic consequences docu- 
mented by Polanyi, the control and embedding of markets, alongside other forms of integration, were reinstitutionalized after 1945 and extended in two basic recipes all over the planet. I see this as the generalization of the most important outcome of the Eurasian longue durée. This era ended in the 1980s. Cessation of rhetorical Cold War hostilities has coincided with a new era of market domination, together with new forms of reaction, benign and malignant. At this moment, the need to rediscover Polanyi's notion of the human economy, and through him the original Eurasian perspective of Aristotle (Polanyi 1957), becomes urgent once again.

\section{Contemporary Dilemmas}

The massive changes that have taken place in global society since the 1970s have attracted the attention of many sociocultural anthropologists (see Eriksen 2003, 2014). Much of this literature takes the form of pointing to the ways in which, in the era commonly labeled "neoliberalism," the increased mobility of persons and capital, especially financial capital, affects specific local outcomes. Ethnographies of capitalism have been plentiful, including the particular forms it takes in the former M-L-M countries, but more systemic analyses of this era in terms of political economy have been rare. One exception is Chris Gregory (1997), who dates the demise of the postwar settlement in the West very precisely to Richard Nixon's 1971 abandonment of the gold equivalent for the dollar in order to finance an expensive war in Vietnam. Other notable accounts of the neoliberal conjuncture include those of Jonathan Friedman (2012), who adapts worldsystems analysis to make sense of it, and Douglas Holmes (2000), who has shown how its logic contributes to the rise of "integral" populist nationalism in many European countries (cf. Kalb and Halmai 2011).

Missing from the accounts produced to date is any recognition of the historically shaped commonalities of Eurasia and their legacy. This is easy to understand, especially in view of the continued political fragmentation of the supercontinent. The United States, still the global superpower, is thoroughly enmeshed at both ends. China, still ostensibly a socialist state, has experienced phenomenal economic growth since committing itself in the post-Mao era to the reform course pioneered in 1960s Hungary. According to many observers, the Middle Kingdom is well on the way to global hegemony, thus demonstrating that Goody's model of long-term alternation has lost none of its validity (see Frank 1998; Pomeranz 2000). But the benefits of this growth have hardly been enjoyed by the majority of the citizens of China. Instead, power holders have preferred to play a servile role toward the United States, purchasing vast quantities of debt and allowing social inequality indicators in the People's Republic to surpass those of its patron (Hung 2009).

At the same time, the United States maintains its unchallenged leadership of the North Atlantic Treaty Organization, the victor of the Cold War. This military alliance has, in the past two decades, recruited most of the former Soviet-bloc states of Eastern Europe and also several states that were formerly members of the Soviet Union. These policies reached a critical juncture in 2014 with the crisis in Ukraine. According to many Western politicians, supported by scholars who had never discarded their Cold War blinkers, Ukraine needs to choose between "Europe" and "Eurasia" (Snyder 2014). By "Eurasia" they mean not the concept of Eurasia advocated in this article, which fully subsumes Europe, but a stymied construction of Russian nationalists. I return to these points in the conclusion.

Washington's astute combination of financial dependence across the Pacific with Atlanticist supremacy vis-à-vis Russia has so far precluded any possibility of rapprochement within Eurasia. The most influential US political scientists have resorted to the concept of civilization only in order to emphasize difference and "clash" (Huntington 1996). But is it too far-fetched to suggest that similar civilizational heritages could shape geopolitical agendas in more harmonious ways? There is abundant evidence that these legacies matter. While China since Mao Zedong is commonly dismissed as a case of "neoliberalism with Chinese characteristics" (Harvey 2005:120), the authorities have in recent years been busy extending systems of social support, and in particular pension entitlements, to millions of citizens not effectively included hitherto. They do so while appropriating the ancient idioms of Chinese philosophy. Ostensibly secular governing elites promote traditional rituals at the birthplace of Confucius and at multiple levels all over the country. This suggests that the political community in China is still closer to evolved Eurasian norms than it is to those of the Tea Party in Washington, with its demands to minimize state "intervention."

The key question is the direction in which China, the emerging superpower, will move next. As the "workshop of the world," China's astonishing economic growth has been made possible through the utilization of crude market advantages. Wages have been held back, and safety standards fall far short of the norms that have evolved in Western Eurasia and in the more advanced economies of the east, while environmental pollution knows no bounds. In short, China, with its vast population, has regained its economic and political strength in ways analogous to those pioneered by Britain in the nineteenth century, through relentless exploitation of the fictitious commodities of labor, land, and money (Polanyi 1944). Appalling workplace and environmental conditions are the result of collusion during the past three decades with Washington, where President Barack Obama has made little progress in his efforts to tilt US society back in the direction of the New Deal and the Great Society. But another outcome of this global collusion is that the countries of Western Eurasia have increasing difficulty in sustaining the mixed, or "social," economies they consolidated after 1945. Labor, the environment, and the common currency have all come under further pressure in the wake of the financial 
meltdown of 2008. Far from leading to a realignment within Eurasia on the basis of common societal values, so far the crisis has induced a return to Cold War skirmishing, and there have been no serious efforts to reform global capitalist institutions (Mirowski 2014; Streeck 2014). By a peculiar twist of fate, when one recalls the message of Aristotle, one of the principal casualties of this triumph of the market over democratic governance has been Greece.

To theorize alternative paths, the tools provided by Polanyi remain among the best available to us. To imagine how such a reembedding of the human economy might in practice be accomplished and last somewhat longer than the trente glorieuses that followed 1945, it is worth drawing attention to the long-term principles that have united Eastern and Western agrarian empires since the urban revolutions of the Bronze Age. It is also worth looking again at the ancient interface between the sedentary agriculturalists and the steppe nomads of inner Eurasia. The nomads have all but disappeared, but their sparsely populated territories and those of the smaller, scattered peoples to the north hold the energy reserves that are vitally needed by the densely populated states to the south. This north-south (or "inside-outside," in the formulation preferred by Arnason 2015) divide will be as important as eastwest differences in negotiating the future of this landmass. Power holders in Moscow and Astana are therefore well placed to initiate an Ausgleich for the entire supercontinent. The basic principles would be those of inclusive citizenship and the mixed economy, a balance of Polanyi's "forms of integration," the fine detail of which would vary according to local historical conditions. In this way the peoples of Eurasia, comprising some three quarters of the population of the globe, would transcend the collective-action problems that have dogged humanity all along and have reached critical proportions in a world of more than 7 billion inhabitants. The new institutions of Eurasian political and economic unity would not repeat the errors of "Fortress Europe" but form the prelude to a genuine world society and government, based on a globally embedded human economy (Hann 2014a).

This utopia would mark the completion of the trajectory commenced more than three millennia before in Mesopotamia. Eurasia, as I have outlined its Realgeschichte, was born and nurtured in the crucible of a historically specific market-state dialectic, accompanied by innovations in the religious-political nexus. The hierarchies of the agrarian era were eventually threatened by the new ones of industry. Many significant changes have taken place in the past two centuries in terms of divisions of labor, the expansion of electoral democracy, and the mobility of citizens. But the egalitarian promise of the Enlightenment was not fulfilled: in myriad ways the myths and repressive institutions of the ancien régime are still very much to be reckoned with in the twenty-first century (Hart 2002). One of the biggest obstacles to this emancipation is the political fragmentation of Eurasia. For all its civilizational pluralism, Eurasia even today is marked by a general commitment to what Polanyi termed simply "society," to values more conducive to human flourishing than the liberal-individualist values that set the tone in most of the New World and other powerful settler societies. ${ }^{9}$ Of course, the latter, too, are products of the long-term Eurasian dialectic, the effects of which were never strictly confined to the landmass and have shaped the history of all the other continents. The dialectic continues within countries such as the United States of America. It continues also throughout the Old World, for example, in China and the Middle East, where the antidemocratic ethos of neoliberalism is exemplified; in Europe, India, and Japan, where consumerist self-fashioning is undermining older notions of community in more democratic political frameworks; and in Russia, which falls somewhere in between these two broad types. The outcomes are uncertain, but I argue that the best hopes to overcome the destructive logic of global laissez-faire are at home in the Old World, where the trajectories began.

\section{Beyond Atlanticist Anthropology}

The concept of Eurasia advocated in this article is in keeping with a substantial body of scholarship challenging Eurocentrism, either by "reorienting" toward China (Frank 1998) or by "provincializing Europe" more generally (Chakrabarty 2000). The point of the Eurasian perspective is to escape from the binary of Europe and the rest of the world. It is to declare Yes, we are the children of the past 500 years, but we are also heirs of much older interactions between the human economy and the religious-political nexus, dating back in the Old World at least 3,000 years.

Sociocultural anthropology has been profoundly affected by this context. As I noted above, Eric Wolf's formulation of Europe and the People without History (Wolf 1982) implies a binary that from my perspective would be better adumbrated over a much longer time period in a volume titled Eurasia and the People without History. Can sociocultural anthropologists dispense with such binaries altogether? The emphasis on comparison and models of science as practiced by A. R. Radcliffe-Brown or George Peter Murdock has gone out of fashion, as have earlier interests in the concept of civilization. But a great deal is lost if anthropology is reduced to particularist ethnographies in the neoliberal present. To the extent that they concentrate on the overseas empires of the most powerful states of Western Eurasia, recent postcolonial critiques continue the bias of the preceding Golden Age, dominated by ethnographic studies of "modernization."

Closer inspection suggests that, compared with other disciplines, the bias of Anglophone sociocultural anthropology nowadays is actually worse than merely Eurocentric. Historians and other social scientists routinely engage with the

9. This claim is based, inter alia, on a mass of evidence gathered in fieldwork-based projects at the Max Planck Institute of Social Anthropology over the past 15 years. See www.eth.mpg.de. 
German-speaking world and with Eastern Europe, taking seriously the scholarly communities of those regions. However, sociocultural anthropology has been dominated for a century by the Atlantic fringe. Germany lost its empire at the end of the First World War, and its anthropologists were further discredited at the end of the Second. Russian anthropologists were also marginalized, albeit for different reasons. Across most of the rest of Eurasia, anthropologists busied themselves primarily with their own peoples, which was enough to disqualify them from the emerging international canon (despite a few awkward cases, such as folklorist-ethnologist Arnold van Gennep). While the Anglosphere still pays lip service to contributions from France, nowadays even these are read only in translation. The undeniable fact is that, in the early twentyfirst century, notwithstanding significant developments in the Hispanic world, one tradition of anthropology is almost hegemonic. It is not surprising that such a discipline, less multilingual than it was in the nineteenth century, has been unable to recognize Eurasia. Overcoming this bias will not be easy, but it is essential if sociocultural anthropology is to realize its original emancipatory critical agenda. A start could be made by developing a comparative historical anthropology that pays as much attention to the overland expansion of the great empires of Eurasia as to the maritime empires of Atlantic Europe in recent centuries. It is high time we began to engage the relevant bodies of knowledge produced in other parts of Eurasia. In this article I have relied heavily on Polanyi and Aristotle for fundamental notions of an embedded human economy, but analogous contributions have been made in other parts of Eurasia, where similar dialectics unfolded.

\section{Conclusion}

It seems, on the face of it, implausible that any spatial concept could possibly be helpful in addressing contemporary dilemmas. The world was already highly globalized in 1944, when Karl Polanyi published The Great Transformation. The intercivilizational connectivity that intensified in Eurasia in the first millennium BCE has long engulfed the entire planet. I have emphasized long-term continuities in the dialectic of political economy. In the agrarian empires, the dominant economic ideology was consistent with the moral-religious concepts that took root in the Axial Age, even if the promise of inclusion was vitiated by staggering social inequalities. The outcomes did not significantly improve, and in some respects deteriorated, when an alternative economic ideology became dominant in the era when those empires were swept away by industrial nation-states. M-L-M socialism can be theorized as a reaction against liberal individualism and a return to the former, collectivist ideology. I argued that the goals of inclusion and equality were best approximated in those places that sought pragmatic combinations of the Polanyian "forms of integration," notably in the mixed economies of Western Eurasia, but also in places such as market-socialist Hungary.
Concomitant with these structural factors, I have emphasized resilient civilizational diversity between the Bronze Age and the present. The impulse to calculate, to "truck and barter" for utilitarian advantage was increasingly salient, but it was everywhere contained by distinctive forms of politics and society - "the other side of the coin" (Hart 1986). The balance shifted decisively toward the market in Britain in the nineteenth century, and it has done so again in recent decades (although in the period in between this country was a pioneer of electoral socialism). Meanwhile, smaller countries such as Estonia have been attracted to neoliberal market ideology as a component of nation building in the wake of achieving independence from the Soviet Union (Lindstrom 2015). The Eurasian model of inclusion, which saw its paradoxical heyday with the geopolitical divisions imposed in 1945, may now be disintegrating before our eyes. Across most of the landmass, including the fragmented states of Western Eurasia, the Gini coefficients of inequality continue to increase.

Despite these trends, I argue that the heirs of the Eurasian agrarian empires, irrespective of which variant of industrialization and socialism they experienced in recent times, have not abandoned the ideals of inclusive embeddedness. The dialectic between community and individual, redistribution and market, may be universal. But only in Eurasia has it played out on such a vast scale over so many centuries to yield results that offer humanity a future - some form of mixed economy, particularly as it evolved in Western Eurasia following the Second World War. The alternative scenario, rejected by Aristotle and Confucius but eventually exported from Western Eurasia and incarnated today by Australia and Canada as well as the United States, is to suppose that freedom and human futures can be predicated on homo economicus and the domination of the market. I therefore argue for an inclusive conception of Eurasia in a double sense, socially and territorially. My expansive territorial usage would become universal if the establishment of a Eurasian political-economic unity were to be the prelude to a world society. If this remains utterly utopian, those fortunate enough to be able to make their living as scholars are nonetheless free to uphold such a concept, to explore its historical roots and probe its potential in the present. We are free to theorize and investigate empirically a Eurasian mental space - analogous to the way Europe is currently specified in the charters and treaties of the European Union. ${ }^{10}$

I noted in the introduction that sociocultural anthropologists maintain a healthy interest in the sociocultural lives of the concepts they use. In concluding, it is disappointing to have to concede that the concept of Eurasia that I have advocated in this article has not enjoyed much sociocultural take-up to date. My concept of Eurasia, pieced together on

10. For contemporary jurists, "Europe" is not a geographically defined territory but a construction, an "espace de liberté, de sécurité et de justice" (Supiot 2008:151). 
the basis of diverse contributions in many disciplines, including the contributions of many authors who do not use the word "Eurasia," is losing ground at the very moment that the word is becoming ubiquitous in the mass media, but with quite different conceptual reverberations. The currents known as Eurasianism in the Russian Federation today have emerged from a revival in the late Soviet period of ideas elaborated by diaspora intellectuals in the 1920s. These ideas have left their mark inside Russia, including on minority peoples of the Empire and its successors, shaping Realgeschichte in the postsocialist present (Bernstein 2013). The political deployment of "Eurasia" in the wake of political crisis in Ukraine in 2014 has brought Aleksandr Dugin's theories of "Orthodox Russian civilization" and critique of Atlanticist conspiracies to the attention of mass audiences in Western countries. These developments may well be increasing the credibility of extreme nationalist doctrines within Russia. But this notion of Eurasia has nothing in common with the concept proposed in this article.

Although my usage is out of kilter with the dominant paradigms in anthropology, I maintain that it has both a solid material grounding and a distinguished academic pedigree in the work of scholars such as Childe, McNeill, and Goody. I have argued that the unity-in-civilizational-diversity of Eurasia can provide a base for global political cooperation to address the "reembedding" agenda of Karl Polanyi's great transformation. Therein lies its critical potential for anthropologists. But for the time being, those who control the means of communication outside and inside academia are bent on deploying the term "Eurasia" to refer to a subset of the supercontinent, with the effect of reinforcing old stereotypes and impeding the potential for unification that is implicit in the historical concept. It remains to be seen whether Eurasia, as I have constructed it within a scholarly tradition, will perish altogether in the face of this competition or whether it can at least provide a serviceable concept for sociocultural anthropology and related disciplines.

\section{Acknowledgments}

This article is an early product of a project supported by the European Research Council: "Realising Eurasia: Civilisation and Moral Economy in the 21st Century" (Seventh Framework Programme, 2014-2019). It owes much to the long-term collaboration between my department at the Max Planck Institute for Social Anthropology and numerous historians and archaeologists of the Martin Luther University, Halle-Wittenberg, in the framework of our research school "The Anthropology, Archaeology and History of Eurasia" (ANARCHIE). I thank in particular Tobias Neuser, one of our first cohort of doctoral students in archaeology. This particular formulation of the argument owes much to political developments in a major Eurasian country in 2014, to excellent working conditions at the Institut d'Études Avancées at Nantes in the academic year
2013-2014, and also to the provocations of the Advisory Board of my institution in April 2014. Special thanks to its chair, John Borneman. Thanks also to John Schoeberlein for the invitation that allowed me to present the argument at a joint conference of the Association for Slavic, East European, and Eurasian Studies and the Central Eurasian Studies Society in May 2014 in Astana; to Catherine Alexander, Kirsten Endres, and David O'Kane, my readers for the version that appeared as Working Paper 157 of the Max Planck Institute for Social Anthropology (July 2014); and to the reviewers for this journal. Other debts can be inferred from my references. In recent years I have had the good fortune to collaborate with Johann P. Arnason, Thomas Hylland Eriksen, and Keith Hart; I continue to learn much from them all. Others to whom I am indebted might prefer not to be named, so I shall not attempt to be comprehensive. This agenda is more speculative, polemical, and political than most academic research, and the plowing of such furrows is ultimately a lonely undertaking. Although experience shows that it is unlikely to help, let me state here (as I have prefaced many talks over the years) that my promotion of Eurasia does not make me a "Europe-basher." Quite the opposite: my concept of Eurasia is intended to salvage the Europe to which I am profoundly attached from the forces currently obliterating it.

\section{APPENDIX}

\section{Rival Usages}

\section{"Eurasia" in the Nationalist Imagination}

"Eurasia" is understood in some circles to refer to a current in Russian intellectual thought associated with Prince Nikolay Trubetskoy, Petr Sawitskii, and other extraordinary men of the post-1917 diaspora (they were indeed all men). Their notions of Evrazija blend elements of romanticism and religious mysticism with political conservatism and materialist geographies. These ideas were revived in the late Soviet period, a revival sometimes termed by foreign analysts neoEurasianism, in which the Russian etnos is postulated even more firmly as the konstanta of the civilization of Eurasia (Humphrey 2002). These are intriguing intellectual, ideological constructions, with some affinities to older European critiques of the Enlightenment. Like Herder, but on a scale larger than the Herderian Volksgeist, Trubetskoy offers an antidote to the rationalist universalism of les Lumieres. This alternative is holistic and organic, opposing spiritual profundity to the utilitarian disenchantment of a technologically more advanced West. It can equally be appreciated as a precursor of the Saidian critique of Western Orientalism and postcolonial theories (Laruelle 2008).

At the end of the day, this remains a closed system of ideas in the Popperian sense (Wiederkehr 2007). It is of no use to me in comparative historical analysis, although, as an an- 
thropologist interested in the social life of concepts, I can of course try to explain its popularity and increasingly reactionary deployment in relation to systemic changes that have marginalized large sections of the population in countries that are themselves marginal to the machinery of the global capitalist economy. (The Russian case is by far the most significant, but Avrasya has been cultivated in comparable ways by reactionary elements in Turkey.)

\section{"Eurasia" in Anglophone Academia and Contemporary International Relations}

The antithesis of such heady intellectual conceptions of Eurasia is the pragmatic sense in which the term has acquired a wide measure of acceptance around the world to refer to a limited number of post-Soviet states. University departments of Russian Studies, such as the program at Princeton University, have added the term "Eurasia" to their names, as have professional associations. Thus, Slavic Review, the premier area-studies journal in the English language, is nowadays published by the Association for Slavic, East European, and Eurasian Studies. The US Social Science Research Council runs a Eurasia program that extends between Galicia and the Mongolian steppe. Kazakhstan has recently established a body called the Eurasian Council on Foreign Affairs, modeled on councils with similar-sounding names in the European Union and the United States. And so on.

This usage largely overlaps the Russian nationalist usage noted above. The congruence is evident in the establishment of the Eurasian Economic Union in 2011. This is a pragmatic initiative in the sense that, unlike the space invoked by the theorists of Russian Eurasianism, it has precise boundaries (those of the member states: initially Belarus, the Russian Federation, and Kazakhstan). Moreover, like the European Common Market in its early phase, the emphasis is currently placed on economic goals: a customs union and the promotion of economic integration. At the same time, in an antagonistic political climate vis-à-vis the West, it is increasingly proclaimed that the members of this Union hold common values and share common civilizational legacies - those of socialism and the Russian empire before it.

\section{"Eurasian" in Biological Anthropology}

The term is popularly used, especially in Southeast Asia, to refer to persons with one parent who is Asian and one who is (white) European.

\section{"Eurasian" (Eurasier) in Zoology}

The term denotes a spitz breed of dog which originated in Germany in 1960 and was later popularized by ethologist Konrad Lorenz.

\section{Comments}

\section{Milena Benovska-Sabkova}

Department of History of Culture and Art History, New Bulgarian University, Montevideo Street 21, corpus 2d, office 613, 1618-Sofia, Bulgaria (mbenovska@nbu.bg; milena.benovska@gmail.com).

25 VI 15

\section{Whose Eurasia?}

The theme of Eurasia has attracted the attention of Chris Hann for a long time (Hann 2003, 2006, 2012, 2014b). On the one hand, his article "A Concept of Eurasia" is a stage in his longtime efforts to determine the theoretical framework for the research strategies of his department, Resilience and Transformation in Eurasia (previously Postsocialist Eurasia), of the Max Planck Institute for Social Anthropology. Another, no less important goal is to provide large-scale synthesis and vision for the rapid changes in the modern world in the historical perspective of the longue durée. In this sense, the reflections on Eurasia far outweigh the efforts toward a semantic clarification of a scientific concept. Hann offers an original theory for the three-millennium development of the vast space including, in addition to the very supercontinent, the southern Mediterranean-North Africa, defined not so much geographically but in terms of human connectivity and models of economic action, cooperation, and integration.

Hann is consistent when he gives due recognition to his intellectual predecessors-Jack Goody and Karl Polanyi, to begin with. Compared with his earlier publications on Eurasia, this article adds further argumentation that allows the author to highlight his personal contributions in the development of a more versatile view of Eurasia supported by a wide range of interdisciplinary evidence. The reflections expressed by Hann go beyond criticism directed against Eurocentrism; in search of the "chemistry" that shapes the appearance of the historic Eurasia, he weaves theories on "Axial civilizations" (by Karl Jaspers, Shmuel Eisenschadt, and Johann Arnason). Two conferences dedicated to "civilizational analysis" organized by Hann testify to the ambition in this intellectual effort. ${ }^{11}$

My position as an author writing these lines from the southeastern periphery of Europe is more than favorable to the idea of Eurasia as integral space. I live in a region "populated" with evidence (including material) for human mobility and intensive cultural exchanges between the different areas of the Eurasian supercontinent at least from the late Bronze Age onward. Along with this, the debatable character of Hann's understanding of Eurasia is an invitation to dialogue. The author himself is concerned about the mixing of

11. "Anthropology and Civilizational Analysis: Eurasian Explorations," Halle/Saale, June 28-30, 2012, and "Inequality, Scale, and Civilisation," Halle/Saale, July 8-11, 2015. See www.eth.mpg.de/3231595/events (accessed June 5, 2015). 
different uses of the name "Eurasia" due to the media popularity that it has gained in recent years, especially in the context of the political crisis and war in Ukraine in 2014: "My concept of Eurasia ... is losing ground at the very moment that the word is becoming ubiquitous in the mass media, but with quite different conceptual reverberations."

It's all about Eurasianism - a political ideology that emerged in the 1920s among Russian political emigrants. It is characterized by anti-Western focus, with the idea of Russia as a symbiosis of European and Asian traditions and with recognition of the contribution of Asian nations to the uniqueness of Russia. This ideology was revived with renewed vigor as a radicalright movement after the end of the Soviet era and after the arrival of President Putin in power-since 2000, it has given a name to a political project whose purpose is the restoration of the Soviet-style relations between Russia and some of its present-day neighbors.

As stated by Hann, this understanding of Eurasia has nothing to do with the concept he proposes. The Eurasian theories in Russia go through different phases, but their essence remains unchanged: in the vocabulary of Eurasianists, Eurasia is synonymous with Russia. Eurasianism is an (ethno) nationalistic movement (Bicilli 2004 [1927]:109; Laruelle 2009: 85; Shnirelman 1996:4, 2006; Umland 2008; Wiederkehr 2012: $10)$. As for the founders of the movement and the modern Eurasians, "the main pathos of the Eurasian movement came down to the preservation at any cost of the wholeness of the Russian state, whether it is called the Russian Empire, USSR or Eurasia" (Shnirelman 2006). The first Eurasians expressed, among other things, disappointment at the refusal of Western governments to provide assistance to Russia against the Bolsheviks (Florovskii et al. 1921). Eurasianists have always seen a serious threat in the "expansion of Roman-German culture" and in Roman-German "cosmopolitan chauvinism." In this respect, the early Eurasianists continued some of the antiWestern traditions of nineteenth-century Slavophiles (Shnirelman 2006). One of the early Eurasianists proclaimed that an "Asian orientation" is possible only for a true Russian nationalist (Trubetzkoy 1922:306).

The emergence of Eurasianism and its revival after 1991 are directly related to the political upheaval after the collapse of the Russian statehood in 1918 and the disintegration of the Soviet Union after 1991 (Wiederkehr 2012:7-9), respectively. Neo-Eurasianism plays the role of an integrative ideology in post-Soviet society. It is, practically speaking, "the only viable ideology that ... legitimiz[es] ... Russia as a multiethnic state" (Laruelle 2007:13). Unlike their predecessors, however, contemporary neo-Eurasianists are not opposed to maintaining contact with extreme right and ultranationalistic parties in Western Europe (Laruelle 2009; Umland 2009). Laruelle (2004) defines the contemporary Eurasianism as "an imperial version of Russian nationalism.” Petr Savickii considered the openness of continental Eurasia to be opposed to the "oceanic" characteristic of Western Europe as a cultural region
(Florovskii et al. 1921). Hann expresses a consonant idea; the similarity between the theories of Russian Eurasians and the concept of Eurasia proposed by Hann ends there, however.

A main feature of Eurasia, Hann believes, is the social and cultural embeddedness of the economy, established for centuries. This feature obtains a specific extension in the Cold War period when Eurasia "is thus better seen as a struggle between two variants of socialism, M[arxist]-L[eninist]-M[aoist] and 'electoral." " Hann examines "the present global conjuncture following the demise of socialism and argue[s] that solutions to urgent dilemmas can be found by building on the historical accomplishments of Eurasia." Is this idea utopian? Hann himself has doubts on this issue; still less might I find an answer. In return, the normative character of this assumption should be noted, despite the assurances of Professor Hann to the contrary - the nonnormative use of the concept of Eurasia (Hann 2014b:4). I am convinced, however, that Hann's concept expresses the humanistic ethos of social anthropology from its first appearances in the early nineteenth century to the present day.

\section{Aleksandar Bošković}

Department of Ethnology and Anthropology, Faculty of Philosophy, University of Belgrade, Cika Ljubina 18-20, 11000 Belgrade, Serbia [aleksandarbos@gmail.com]).1 V 15

Analyzing how geographical and political borders are constructed, created, and recreated has been very prominent among British scholars in the twentieth century; one is reminded here of Toynbee's (1934-1961) highly ambitious multivolume project, where he claimed that the "civilization" should be the main unit of the study and analysis, unlike the "nation-state," for example. The term "civilization" can provoke some unpleasant reminders for sociocultural anthropologists, given Tylor's (1871:1) famous description and conflation of "culture" and "civilization," but I do not wish to go into our discipline's unpleasant evolutionary past. It is interesting to note that Toynbee was also among the scholars who were very clear in their criticism of Eurocentrism, especially with reference to Asia (Toynbee 1954). ${ }^{12}$ It is very good that Chris Hann refers to Lewis and Wigen (1997) - the idea of geographical units, and continents in particular, as "constructs" is a very useful one. It was pointed out even earlier than Toynbee, in the 1930s, by one of the most influential authors of the past century, Michel Leiris, who was using the example of "Africa" (Leiris 1996; Bošković 2003), and perhaps the most powerful de-

12. On the other hand, Western scholars frequently ignore representations of "the West" in ancient Chinese or Korean manuscriptswhich are just as offensive as "Western" attempts at "orientalization" (Whitfield 1994). 
scription of how part of a continent ("Latin America") was invented in the sixteenth and seventeenth centuries was presented by Morse (1988). ${ }^{13}$ Another point that should be taken into account is that these processes of construction are frequently more complex than they might appear-as can be seen, for example, in the way in which "the Balkans" was constructed in both scholarly and popular imagination (Bošković 2010). On the other hand, when Lewis and Wigen claim that France should (because of its size) be perceived similarly to the Indian state of Uttar Pradesh, they obviously do not take into account the political influence that France has had in the world affairs over the course of human history, which is somewhat greater than the influence of the Indian state.

However, when proposing the new ways to construct the unit of anthropological analysis - and the "Eurasia" that Hann proposes seems to be such a unit - it is worth asking questions about what constitutes the new concept (or new "optic," to use Hann's term). Almost in passing, Hann gives opinions on two countries that should form the part of this new construct, Estonia and Kazakhstan. Unfortunately, the issues of clearly defining the wider constructs that are being revisited in the article remain open. Because of space limitations, I concentrate on only one of them.

Culturally and politically, the term "Europe" is used by the residents of the former socialist countries, including Serbia and other countries of the former Yugoslavia (what Czeslaw Milosz used to call the "other Europe"), as synonymous for modernization and progress. In this sense, the process of "Europeanization" came to mean development of democratic institutions after the fall of totalitarian regimes as well as strengthening of the "culture of human rights" and development of civil-society institutions - something that our colleagues in Western European countries seem to take for granted.

Geographically, the concept seems to have been invented by the Greeks Anaximander and Hecataeus in the sixth century BCE, and this was accepted by Herodotus a century later. The Roman geographer Strabo, in the first century CE, thought that the eastern border of Europe was the river Don. While the concept of "Europe" has been used since the eighth century CE in order to refer to Christian and (mostly) Latin societies - in contrast to Byzantine and Islamic influences that gradually come from the west and from the south - it was only in 1730 that Swedish geographer Philip Johan von Strahlenberg proposed the Ural Mountains as the eastern border of the European continent, something that was gradually accepted. However, ever since the Renaissance, the concept of "Europe" has acquired another meaning: it became associated with the idea of progress and constant development. Renaissance "Euro-

13. There is something to be said about the selectiveness of presenting some of these points of view: Leiris's 1934 book was never translated into English, and Morse's book, though originally written in English, was published only in translation. peans" still did not define themselves as such, but made every effort to distinguish themselves from those who were not European (Bošković 2014:57). The idea of "Europe" is a very recent one, the feeling of sharing a common ancestry and some cultural traits going back perhaps no farther than the end of the First World War (Wintle 2002).

All that said, the emergence of a new, more global identity is perhaps a distinctive possibility (although its usefulness for comparisons - and even its exact geographical limits, according to this article - remains a bit vague), but, given the time that was necessary for a "European" identity to emerge, quite unlikely in our millennium.

\section{Thomas Hylland Eriksen}

Department of Social Anthropology, University of Oslo, PO Box 1091, Blindern, N-0317 Oslo, Norway (t.h.eriksen@sai.uio.no). 1 V 15

A bold, untimely or perhaps especially timely article, this programmatic essay by Chris Hann aims to justify a concept of Eurasia as a superregion in anthropology. Hann draws especially on Jack Goody's voluminous comparative anthropology and Karl Polanyi's substantivist economic history, which - unlike Goody's work - is currently being rediscovered after decades in the doldrums.

Anthropologists tend to be splitters rather than lumpers, and delineating large-scale regions is rarely applauded - rightly so, given our professional predilection for the primacy of the local and particular. This attempt to define a superregion is refreshing and well argued, and the critique of anthropology's provincial gaze is highly pertinent, but there are a number of outstanding problems, both formal and substantial, with this concept of Eurasia. Yet Hann should be applauded for his willingness to engage with some of the large questions of a comparative anthropology that has been sidelined for many decades now.

The main argument for conceptualizing Eurasia as a whole is that stratified (tributary or feudal), literate societies with urban cores (and imperial ambitions) arose in various places on the continent during and after the Axial Age and, implicitly, that a similar development has not taken place elsewhere. This is consistent with Goody's contrasting of Eurasia with Africa. Hann also argues that "inclusive embeddedness," that is, a holistic conceptualization of the economy-society relationship in the vein of Polanyi, is a deeply historically rooted feature of Eurasia. A concept of Eurasia could thus critically address not only a version of academic Eurocentrism but also marketization and neoliberalism.

The conceptual discussion, and the plea for its geopolitical relevance in the contemporary world, is enlightening and interesting. Yet in the end it appears chiefly as a political argument about a need in Europe (and North America) to engage with Asian countries - especially Russia, but also China - in a more equitable way. (The omission of the Indian subcontinent 
and, to some extent, the Arab-speaking countries is nevertheless unfortunate.) The plea for a concept of Eurasia, rather than one of, say, the North Atlantic region ("the West"), may be historically rooted, but the present has many genealogies. While Ian Morris, in Why the West Rules-for Now (Morris 2010), takes a position that is similar to Hann's and Goody's in considering the entire landmass (although he does not use the word "Eurasia"), his argument concerns not what holds it together but the causes of Western supremacy, which in his view precedes modernity by several millennia. As Hann knows better than most, other scholars have taken the Muslim world as a relevant entity, exploring its expansion and extent from West Africa to Southeast Asia, while others may consider the Indo-European language area as a relevant cultural macroregion. Briefly, the analytical benefits of an inclusive concept of Eurasia remain unclear.

The question of boundaries remains difficult. Although Hann hints at recent literature distinguishing between central and peripheral parts of Eurasia, it would seem, empirically, that many parts of the continent do not fulfill the criteria set out. Kinship organization remains a strong political principle, frequently opposed to the state, in much of the landmass, and in the arid and semiarid regions covering much of Eurasia, nomadic forms of political organization have been predominant.

The empirical parts are largely devoted to discussions of large-scale and long-term history as well as contemporary geopolitics. I should have preferred a justification of the allencompassing term "Eurasia" with reference to specific historical or contemporary societies. That socialist Hungary had commonalities with social democratic Britain is not very surprising; it would be more exciting to read about the commonalities between, say, Japan, Kazakhstan, and Greece.

An implication of the concept of Eurasia is that it can be contrasted with what it is not. The Polanyian ideals of economic embeddedness are invoked on behalf of Eurasia, while the Anglophone New World settler colonies, by contrast, are said to incarnate homo economicus. But, as Hann readily admits, these colonies were founded and settled by migrants from Britain, where much of the market ideology originated, and both Canada and Australia maintain welfare states modeled on and similar to the European ones, while many Asian states lack both the ambition and the ability to do anything of the kind. Goody's historical anthropology contrasted Eurasia with sub-Saharan Africa, which lacked the institutions of feudalism and the state, but surely, inclusive embeddedness can also be identified in African societies that were historically based on subsistence agriculture. And is the market-state relationship in India really so different from that in Ecuador or Argentina? These complicated questions need to be raised and dealt with empirically for the boundaries of Eurasia, and its substantial characteristics, to come across as meaningful and necessary for a comparative anthropology of the scope and scale envisioned by Hann.

\section{David N. Gellner}

Institute of Social and Cultural Anthropology, University of Oxford, 51 Banbury Road, Oxford OX2 0AU, United Kingdom (david .gellner@anthro.ox.ac.uk).27 VI 15

Chris Hann's article is deceptively simple in its exposition but simultaneously complex, both in terms of the amount of evidence below the waterline, as it were, and by virtue of the fact that (to shift metaphor) a number of balls are in the air at the same time. Hann advocates a concept of Eurasia as a singular place with a singular history, with repercussions to the present day. He follows in Goody's footsteps, with his vision of African exceptionalism. At the same time, Hann is conducting several arguments both for and with Goody, Polanyi, and Arnason, as well as with those who mean something quite different by "Eurasia" (a territorial version of the Russian soul, among others). There is an argument, both analytical and normative, about the embeddedness of the economy - whether from Aristotelian, Confucian, social welfarist, or communist viewpoints - within other sociopolitical structures. On top of all this, Hann also has an argument about the nature of sociocultural anthropology and its hegemonic forms, which he takes to be hostile to the kind of historical and materialist theorizing that he is advocating. On the whole, I believe he is right on this last point, and the bulk of my comment is an attempt to nuance this judgement.

On the first argument - that the names "Europe" and "Asia" derive from an ancient Eurocentric bias, that we need to think beyond not just the nation-state but the "continent"-Hann may in fact receive more support (or less resistance) from sociocultural anthropologists than he expects. Criticisms of methodological nationalism are by now quite widespread and even perhaps taken for granted within anthropology (Gellner 2012; Gingrich 2010; Wimmer and Glick Schiller 2002). Arguments against conventional area-studies divisions of the world are also widespread. Particularly influential in my own area of expertise are statements by Van Schendel (2002), who coined the term "Zomia," and Scott (2009).

Scott announces, in the opening to his book The Art of Not Being Governed, that all he is doing is recycling the arguments and evidence of others. But he does so, as usual, with unrivaled eloquence and great scholarship. Scott's opposition of kingdoms in the rice valleys, on one side, and state-evading Zomia (the uplands where armies can penetrate but not control), on the other, is essentially the same as Hann's contrast between civilization and the pastoral/huntergatherer peripheries. Scott's formulation has already been highly influential. He limits his analysis to Southeast Asia and claims that it no longer applies today, but others have thought it possible at least to ask whether his work might not apply much farther west and into the present day (Gellner 2013; Krasner 2011; Michaud 2010; Shneiderman 2010). Specialists of Southeast Asia, meanwhile, have sought to critique many aspects of the thesis (Hickman 2013; Wouters 2012). Scott's 
influence and the wide-ranging debate he has provoked are surely very much in the materialist, history-aware, direction that Hann would approve of.

A side question would be, What indeed is the role of South and Southeast Asia in this vision of Eurasia? Do they form an equally important axis, alongside China, or are they a sideshow? Does Eurasia dribble out into a fuzzy, Zomian periphery as it encounters the islands of Southeast Asia? (And, by the way, South Asians routinely refer to West Asia, rather than the Middle East, which they quite rightly see as a parochial and outdated term.)

In his dispute with the dominant Anglophone tradition of anthropology, Hann identifies ethnographies of modernization as the principal enemy (to adopt a Marxist phrase) - but I would dispute that. There is no reason why ethnographies of modernization, if properly framed, should be in contradiction with the story Hann wants to tell. Rather, what he should fear is the aspiration to turn sociocultural anthropology into a form of philosophy, the main task of which is to overcome dominant dualisms (agency/structure, individual/society, mind/body, actor/thing, nature/culture) and to enter into alternative cosmological modes of thought. The aspiration is to do precisely what Hann says is "hard even to imagine," namely, to reconstruct anthropology using non-Eurocentric forms of thought and concepts, to overcome the parochial nature of the discipline, born as it was out of the Enlightenment in Europe. The problem is that, in practice, such approaches essentialize the cosmologies they describe and place them all on an equal footing; but worldviews, like languages, are not all equal and never have been. By omitting all reference to history, politics, class differences, economic constraints, and inequality - in short, to different forms of power-an individualist and idealist ideological hegemony emerges that is indeed inimical to the kind of anthropology Hann stands for.

It may indeed be time to stand back, as Hann argues, from the Eurocentric geographic constructs that have dominated history and the social sciences - perhaps inevitably, given the history of the past 500 years. And it surely is also time to rethink the "uniqueness of Europe" thesis and embed it in much wider and longer-term processes. In the end, a short article can be only a manifesto for such an ambitious idea. It needs monograph-length treatment to do it justice.

\section{Andre Gingrich \\ Institute for Social Anthropology, Austrian Academy of Sciences, Apostelgasse 23, A 1030 Vienna, Austria (andre.gingrich@univie.ac .at). $1 \mathrm{~V} 15$}

From Karl Marx to Edward Said, many authors have addressed a core topic through their visions about the future while also relating it to academic analyses of history. Let us discuss the visionary dimensions in Hann's outline of "Eurasia" first. He employs the concept for promoting inclusive embeddedness. This is honest and helpful, since it discloses the core values orienting his entire proposition and makes it accessible. Sharing Hann's sympathies with a priority for these values, however, is not necessarily identical with supporting his notion of "Eurasia" as a vision. In this regard, I prefer more pragmatic avenues, such as the improvement and eventual transformation of existing regional associations - that is, in "Eurasia" the Association of Southeast Asian Nations (ASEAN) or the European Union, in the Americas the North American Free Trade Agreement (NAFTA) or Mercosur. Moreover, it is not enough that the author clearly marks his distance from Stalinist legacies and current Russian usage. If anthropologists in the 1930s had suggested a completely new, non-emic, and visionary notion of "fascism" as a critical scholarly concept that was totally unrelated to Mussolini's and Franco's usage of the term, then such a hypothetical suggestion still would not have been useful. If anthropologists of the 1960s would have proposed a radically alternative usage of the "free world" concept into our field's debates, entirely different from how Dwight D. Eisenhower and Lyndon B. Johnson were employing the same term, then these anthropologists nevertheless would have failed for good reasons. In spite of its affinity to values of inclusive embeddedness, the visionary dimension in the "Eurasia" argument thus is not really convincing at this point.

The historical dimension in the argument is more interesting and perhaps also more rewarding for discussion in a journal like Current Anthropology: the proposition relates "Eurasia" primarily to specific extensions of land/space ("the entire landmass") and eras/time ("from roughly 1000 BC" to "the end of the eighteenth century"). In that regard, this paper offers two basic contributions that are welcome and deserve continuing debates and reflections. First, Hann's thoughtful reappraisal of, and critical engagement with, important scholars in the field's history as it intersects with this topic is highly welcome and very useful. The points made on V. Gordon Childe and Karl Polanyi are particularly well taken, while the discussion of Jack Goody's work is more detailed, and some of its aspects do remain open for debate, such as Hann's claim that "Goody pays too little attention to ... embeddedness," which I tend to regard as somewhat too harsh.

Second comes what is at the historical and empirical core of Hann's argument for "Eurasia" as a historical concept, that is, "civilizational interconnectedness" in the periods and regions under scrutiny. As a member of the Scientific Advisory Board at the Max Planck Institute where Hann is a director, I am aware that his paper is just one result from an ongoing research process. I thus confine myself here to three short points for future consideration. In methodological and empirical terms, a much more inclusive and dialogical approach toward recent and ongoing findings and insights by archeologists, philologists, and historians is required to advance anthropologists' discussions on historical "interconnectedness" among complex agrarian and nomadic societies in Asia 
and Europe. It would be not merely unwise but unprofessional to continue the debate without seriously engaging with contemporary research in these neighboring fields.

This is why, for my part, I remain somewhat cautious with regard to one conceptual component in this argument's historical dimension. Up to now, philologists, as well as historians, have remained fairly skeptical of the concept of the "Axial Age." In addition to academic minority opinions of contrasting views, a majority of scholars seem to have remained largely neutral or indifferent. A serious engagement with historians therefore cannot take the "Axial Age" for granted but has to argue the case. In addition, the critical point remains that, even in its historical dimension, the notion of "Eurasia" may tend to attain too strong an exclusive aspect if elevated to the status of a world-historical concept. The premodern histories of the regions known as Madagascar and Ethiopia, for instance, testify to early and enduring "interconnectedness" between sub-Saharan Africa and Asia as well.

Is it useful and necessary to consider the more intense interactions between complex agrarian and nomadic societies of Asia and Europe before 1800? For certain questions and research problems it is not, while for others it is absolutely indispensable (Gingrich and Lutter 2015). For these, one may employ the concept "Eurasia" not as a world-historical concept but as a useful, rich, yet open research tool. So in sum, I would argue that this glass is not almost empty but half full: Chris Hann has reopened a debate that should be continued.

\section{Nikolay Kradin}

Institute of History, Archaeology and Ethnology, Far East Branch, Russian Academy of Sciences and Far Eastern Federal University, Vladivostok, Russia (kradin@mail.ru). 8 V 15

The general thrust of the article by Chris Hann is good and sympathetic. In fact, the term "Eurasia" in the Western mass media has frequently been regarded over the past years in an Orwellian sense as a synonym for a bad totalitarian empire that stands up against the good democracy. Appositely, the origins of this myth date back to the Greeks. Hann is writing correctly on the matter.

Russian Eurasianists also have understood the term "Eurasia" narrowly. I will never forget how, in the period of perestroika, the restricted-access collection (spetshran) was opened in the main library of the USSR (Lenin Library in Moscow). I then read many books, and Oriental Despotism by Karl Wittfogel and some books by George Vernadsky were first among them. In one of Vernadsky's books, I saw a cyclic scheme of integrations and collapses in Eurasia. After the Russian revolution (collapse), the USSR (integration) was followed by three question marks. I laughed to myself at the Great Eurasianist. If only I could have thought that only 2 years later the biggest country in the world at that time would not exist!
But these are my personal feelings as a man who turned out to be a witness of these epochal changes. There is much self-reflection in Hann's paper. He was also a bystander of those events, but he was at the other end of the continent. Rueful personal feelings are an important part of the anthropologist. But I should think that Hann must give consideration to argumentation in order to convince the readers that Eurasia is really a united world. What arguments can there be?

In the first place, these is evidence of significant relations between the eastern and western parts of Eurasia, if only in brief. World-system analysis reveals four types of networks: prestige goods, political, military, and information. The networks of information and prestige goods are the widest ones (Chase-Dunn and Hall 1997). As an anthropologist and archaeologist of nomadism, I see much local evidence of contacts in cases of exchange of prestige goods and movements of people. In recent decades, there have been a considerable number of such discoveries in the Xiongnu archaeology. These include a cup of Roman glass from the elite burial place Gol Mod 2 and a magnificent disk featuring the goddess Artemis and a satyr from elite tomb 20 at Noin-Uul. There is a tomb of a European warrior (born in the Roman Empire) in the burial place Durlig Nars in Mongolia. I must also mention the grave of a woman in Vanyari, Italy, who was born in South China (Kradin 2014:108-109).

Among the major results of information exchanges throughout Eurasia are the origin of agriculture, the domestication of the horse, the distribution of chariots, bronze and iron metallurgy, stirrup, sabers, and many other military technologies. A separate matter is germs and epidemics. Most of the abovelisted discoveries or factors fall into several large waves: Xiongnu (between the Roman and Han empires), Turkish (between Byzantium, the Arabs, and T'ang), and Mongol globalization. The new Chinese projects (the New Silk Road and a high-speed railway from China to Alaska through the Russian Far East) can promote communication by their global dimension (as did the old Silk Road).

One more important question is a synchronism in the rise and decline of large states and empires in the different parts of Eurasia. This was noticed by Teggart (1939). Subsequent researchers have confirmed this correlation (Chase-Dunn et al. 2010; Taagapera 1978; Turchin 2009). Now the causes of this synchronism should be explained. In addition, it is essential to ask how we can forecast the rhythms of large states in Eurasia in future. What is waiting for us?

There are many real relations, but it is declared ideologically that there are few. As anthropologist, I struggle constantly with the manifestations of the first and second ones. A few years ago, at the passport checkpoint to Schengen zone, I was told "You are entering Europe." I objected, "Russia is Europe, too." The frontier guard whipped out a reply: "Europe is Schengen." It is obvious that a new identity that assigns to only itself the old common name is being newly constructed. On the other hand, there is a global diffusion of ideas without 
borders. Once, in Kazakhstan, my colleague professors complained that public servants adapt all bureaucratic novelties in the education from Russia. I was surprised. But I was yet more surprised when, in France, I began to complain of the growth in bureaucracy, the integration of universities and scientific laboratories, and the merging of universities. My conversation partner, a famous scholar and professor, told me that a similar situation holds in France.

I am heartily glad that, on pages of a leading worldanthropological journal, the theme of the unified world of Eurasia has been taken up. We all are dissimilar, but we live in the one global world, the parts of which are linked. Eurasia is not only a consolidated continent. In some ways, it is the first example of the experience of conflicts and consent between different civilizations and cultures within common territory. It is also important as the most-extended-in-time project (longue durée). Therefore, this experience is significant for construction of a common home under the sun in future.

\section{João de Pina-Cabral}

School of Anthropology and Conservation, University of Kent, Marlowe Building, Room 16b, Canterbury CT2 7NR, United Kingdom (j.pina-cabral@kent.ac.uk).6 V 15

Chris Hann's piece brings two very important aspects to our attention. On the one hand, anthropologists are bound to discuss explicitly their regional engagements (Pina-Cabral $1989 b$ ); on the other, social scientists must exercise a critique of the ethical and moral challenges of their day.

I find, however, that I am uncomfortable with Hann's notion of a "long-term unity of Eurasia." In particular, his exclusion of sub-Saharan Africa seems hard to defend. Moreover, in claiming that "Eurasia even today is marked by a general commitment to ... values more conducive to human flourishing than the liberal-individualist values that set the tone in ... the New World and other powerful settler societies," he polarizes human experience into a corporativist tradition versus an individualist modernity, another version of the archaic/ modern polarity. His identification of "the market" with "individualism" runs counter to the lessons of ethnographic comparativism. One is bound to agree with him that neoliberal ideology has led to an excessive concentration of wealth at global level (Piketty 2014). This is a highly problematic process in terms of both human well-being and world sustainability. But to start from this and then go on to a demonization of market relations seems unwarranted.

The matter, however, is an old one in the discipline. Should anthropologists work with regions unitarily defined in terms of "culture traits"? For example, is the existence of sociétés à maison (oikos) really a specific Eurasian feature, as Hann defends? It is not (Pina-Cabral 1989a). To my mind, we are better off arguing adjectivally about Eurasian continuities and tendencies than arguing substantively about the unity of Eurasia.
Socioregional differentiation cannot be approached aside from the superimposed and polycentric processes that characterize human history. In this respect, and in spite of all the problems that I recognize in it, Beckwith's (2011) proposal of seeing the Central Eurasian civilizations as dynamic integrators of the Eurasian landmass, with the two lands of empire functioning as schismogenic poles on each side of it (East and West), seems far preferable to me and far more sustainable in empirical terms.

Second, Hann's argument concerning Eurasian communalities, or how "to harness older notions of society," is problematic. While I value a rereading of Polanyi's work, I cannot very well see how the values of communality characterize Eurasia more than Africa, Oceania, or the Americas. Have we forgotten the lessons of such classics as Monica Wilson's Good Company (1963 [1951])? Furthermore, none of us can honestly disagree concerning the horrors of "Fortress Europe": it is, after all, 15 years since the first corpse of a migrant floated onto the beaches of the Canaries. Europe, as dominated by the global banking elites, has turned into another example of a humanly destructive state-structure, of which we have had so many in the sorry history of Eurasia. But this surely cannot be used as an excuse to validate all the evil policies that are emerging in other Eurasian lands. To the contrary, if we are social scientists and seek "de-ethnocentrification," we have to hold on fast to the ecumenical ideals of European integration (Pina-Cabral 2014).

Finally, I find that we must not confuse English or American hegemony with the use of English as a global language of science. There is today a generation of anthropologists around the world that does not ally itself to any of the old imperial traditions of anthropology - a "global" canon is slowly emerging (Hann 2005). If we peruse the pages of journals such as Social Anthropology, HAU, Ethnos, Fokaal, or JRAI (Journal of the Royal Anthropological Institute), we can observe that it is not true that French ethnologie, Spanish folklore, Italian history of religion, or Brazilian Amerindianism are being cast into oblivion.

\section{Gustavo Lins Ribeiro}

Universidad Autónoma Metropolitana-Iztapalapa, Mexico City; Universidad Iberoamericana, Mexico City; and Instituto de Ciências Sociais, Universidade de Brasília, Campus Universitário Darcy Ribeiro, Asa Norte, 70919-900, Brasilia, Brazil (gustavor@unb.br). 1 VI 15

Chris Hann has written a most welcome essay, a programmatic text openly engaged in contemporary utopian struggles, a move I cherish in view of the current dearth of progressive utopias, of critical interpretations in the present about the meaning of the future, to paraphrase Paul Ricoeur's (1986) definition of utopia. In the vast picture Hann draws, he also recovers the important role anthropologists and other social scientists have played in analyzing large-scale historical pro- 
cesses and disseminating alternative visions. One of his main goals is to go beyond Eurocentrism, another valuable endeavor. But I fear that in the end he is offering us Eurasiancentrism, another kind of centrism, however larger and more complex it may be.

Hann's discussion on classifications resonates with Edward Said's critique of Orientalism and also reminds us of the difficulties surrounding the naming of other world areas, such as Latin America: for some, an invention of Napoleonic geopolitics, for others, a legacy of the great Cuban thinker José Martí. Social scientists know that such taxonomic devices are power devices, since they are related to the building of collectivities and political bodies. The links between places and names turn into geopolitics embedded in nation-states' political power. Since, more often than not, the labels are invented "concepts," they cannot be taken for granted. Dussel (1993), for instance, shows how Europe and the West are historical inventions useful to bypass or to hinder the contributions of other peoples of the world, especially the Muslims, to "civilization." In the same vein, it is hard to understand why Hann does not acknowledge the role Iberians played in Europe's expansion and the formation of the world system. Dussel (1993), again, is critical of readings of Europe's history that are fond of the Anglo-Saxons' agency but exclude different contributions to the making of modernity.

My main argument is that Eurasia appears as an almost self-contained megacontinent. The material and conceptual borrowings from other world areas are not taken into account. Quite to the contrary, Hann's definition extends Eurasia to "the northern zones of the continent known as Africa." But the Islamic contributions to the making of Eurasia are not acknowledged in spite of a great dissemination of sophisticated Muslim philosophical and scientific ideas and technologies in European lands and the almost 800 years of Muslim presence in today's Portugal and Spain. The New World is another absence. I am referring not only to the transfer of gold and silver to Europe but also to the impacts, for instance, of crops, such as potatoes and corns, in European diets and political economy (Thompson [1964 [1963]; Warman 1988) as well as to the interconnections and changes generated by the sugar plantations in northeastern "Brazil" and the Caribbean (Furtado 2007 [1959]; Mintz 1985). The impacts of lowland South America in the European imagination cannot be overlooked, either. In reality, the first-ever utopia, Thomas More's book published in 1516, is located in the South Atlantic. The role that news of bon sauvages played in the construction of philosophical discourses in Europe, influencing such seminal authors as Montaigne and Rousseau, is well known. Sailors, pirates, and slaves disseminated ideas of freedom and societies without state, class division, and exploitation across the Atlantic in a triangle formed by Africa, the Americas, and Europe, influencing Northern radical imaginaries (Linebaugh and Rediker 2000). The ongoing revisionist debates in American historiography about whether the Iroquois played a role in shaping the American Constitution and ideas of democracy is another indication that cross-fertilizations among different places of the world system cannot be simplified.

Being more inclusive than Europe, the concept of Eurasia is certainly an interesting option, but it also seems to be an effect of the changing geopolitics of the continent, especially a response to the emergence of China as a global superpower and to Russia's changing roles. But it would have been interesting to address India's presence as an increasingly important global and regional player.

In spite of recurrent historical and current empirical contrary examples, Hann believes that Eurasia is the best source of ideologies and utopias of inclusion. In the globalized world, it is hard to maintain that one single locus or collective subject, no matter how complex it may be, is able to provide universal political answers. Rather, I believe that to find new progressive global metanarratives, we need a huge effort of articulation of cosmopolitics grounded in different global fragmented spaces (Ribeiro 2003, 2014b). The acceptance of heteroglossia and diversity is a possible solution, in global politics and scholarly life (for anthropology, see Ribeiro 2014a and Ribeiro and Escobar 2006), in the face of the imperial monological hegemony of the Anglo-Saxon world. In sum, Eurasia is a welcome addition to global critical dialogues, but it would be much more thought-provoking if the concept were devoid of centralism and universalism.

\section{Douglas Rogers}

Department of Anthropology, Yale University, 10 Sachem Street, Box 208277, New Haven, Connecticut 06520, USA (douglas .rogers@yale.edu). 18 V 15

Of the many new optics proposed and circulating in anthropology these days, it is rare to come across one that takes a region-rather than, say, a theorist - as its starting point. The promise of Hann's invitation to reflect on Eurasia as an orienting concept therefore deserves some special attention, lest it be dismissed as a musty exercise in an older "anthropology of world regions." On my reading, it is far from that. Among the many intriguing insights and leads in this programmatic piece, let me highlight three.

First, Hann's concept of Eurasia extends in new directions a line of argument that has been developed by many of us who, like Hann himself, have worked in the socialist and postsocialist worlds. This line of argument runs, in brief, as follows: the end of the Cold War and the extension of Western anthropology into the former Soviet bloc-in which I include the crucial importance of collaboration and conversation with scholars based at universities in the region-can generate new insights for anthropology, and indeed social science, as a whole (e.g., Chari and Verdery 2009; Rogers 2010). One of the best ways to make this argument is through the provincialization of the Western European, Euro-American imperial, and, in Hann's apt phrasing, Atlanticist focus of so 
much anthropology. Although that large body of scholarship does not, in general, advertise itself as region based, the view from the socialist/postosocialist world - and Hann's understanding of Eurasia as well-shows the extent to which it actually is and goes on to demonstrate the analytic promise of starting elsewhere, with an alternate geographical imaginary.

However, and this is my second point, Hann's concept of Eurasia opens up some welcome possibilities that have not yet been available to scholars approaching these issues from within the socialisms/postsocialisms rubric. Most enticing to me on this score is the incorporation of very long-term histories and the associated opportunities for cross-fertilization between archaeological and sociocultural anthropological research. Hann sticks fairly close to Goody and Polanyi for this early period, but many more opportunities lie down this road, especially in light of increasingly fruitful conversations between sociocultural and archaeological anthropology on the topics of materiality, infrastructure, and political power. Let me give a brief example. Today's Eurasian energy politics and infrastructures - from the North Sea oilfields and Algerian gas fields to the Eastern Siberia-Pacific Ocean pipeline-are the subject of enormous interest across academic disciplines, including, increasingly, in anthropology. Moreover, discussions of this topic are probably one of the ways in which Hann's Eurasian territory is most commonly invoked in the world of public policy and geopolitics today (although not, of course, in the terms he sets out). What would it mean, then, to consider these pipeline routes and political struggles in light not just of earlier decades and centuries of the hydrocarbon era but also of millennia of materially inscribed Eurasian landscapes, trade routes, interdependencies, and strategies of state and imperial legitimation? Casting discussion of Eurasian energy these terms would not only add historical insight to the issues at play but also go some distance toward pushing back at the narrow understandings of "Europe," "Asia," and "Eurasia" that are invoked and perpetuated through those discussions.

Finally, near the end of his article, Hann presents the decoupling of his social and territorial notions of Eurasia- and the potential spread of those social notions to other parts of the world - as an "utterly utopian" possibility, to be contemplated mostly in the context of a potential "world society." That is fine as far as it goes, and it warrants no less appreciation and no more eye rolling than the many utopian visions that have emerged from Atlanticist anthropology. But I am concerned that Hann locates this decoupling of social and territorial notions of Eurasia only in the future conditional tense. Surely it is the case that an array of such worldwide movements, encounters, and intersections involving notions of inclusive embeddedness that have Eurasian roots - well short of "world society" but quite significant nonetheless - are also to be found in past millennia. Leaving some space for past decouplings of social and territorial in the overall picture would seem only to enhance and further elaborate the utility of Hann's Eurasia optic for posing new questions about the past three millennia.

\section{Günther Schlee}

Max Planck Institute for Social Anthropology, PO Box 1103 51, 06017 Halle/Saale, Germany (schlee@eth.mpg.de). 10 VII 15

Chris Hann is to be credited for some improvements. In earlier publications on the same topic, he speaks of the "unity of the landmass" (Hann 2008:147) and the "basic unity of Eurasia" (Hann 2014a). These formulations have now been replaced by "unity-in-civilizational-diversity." When he writes of "the interconnectedness of the Eurasian landmass," it is unclear whether this implies more connections within than without and whether some or all of these interconnections can be found exclusively on the "landmass." This allows a softer interpretation of these concepts, one that does not have these implications. On the whole, Hann seems to have been forced to abandon some of his stronger propositions.

The earlier versions suggested that Eurasia could be regarded as a cultural unit, with marked internal differences in the form of different "civilizations," which could even be taken as independent variables for explaining different forms of "moral economy" (civilization $A$ producing moral economy $x$ and civilization $B$ moral economy $y$ ). But, despite such internal differentiation, Eurasia was still thought to display a fundamental unity, so much so that one would have expected the cultural or "civilizational" differences separating parts of Eurasia from regions outside of it to be greater than those within it. With this kind of cultural classification, Hann invited commonsense counterarguments (Are the Portuguese really more similar to the Koreans than to the Brazilians? Does the egalitarianism of sub-Saharan pastoralists not look rather "Eurasian" in Hann's sense?) as well as unfavorable comparisons with better-founded forms of cultural classification.

What Hann still postulates in the present version is that the old civilizations of the "Axial Age" have remained in contact with one another and have found their continuation in modern socialist and welfare states. The notion of the Axial Age is contested (see Bowersock 2013), but let us accept it for the sake of the argument. According to Hann, notions derived from the Axial Age have now penetrated into the remotest parts of Eurasia, in some areas quite recently, so that they now constitute a shared framework of values. If this is so, have they not penetrated into the rest of the world as well, arriving in some areas even much earlier than they did in Siberia?

Other changes in this new article touch on the relation between Eurasia as an empirical finding and Eurasia as a political utopia. Statements about the past can be subjected to historical criticism, statements about the present to empirical scrutiny. Self-declared "utopias" are immune to all this. There is no way to show that they are wrong; they lack falsifiability in the Popperian sense. But utopias can be subjected to criticism of their desirability, their plausibility, their realist chances of shaping future realities, and their comparative advantages over alternative plans for the future. Notably, Hann's utopia remains much paler here than in his 
article of 2014 (Hann 2014a), where we learned that the Eurasian Union should have a capital city (Astana) and a common currency (the Avra). Here he restricts himself to saying that the political union of Eurasia should precede that of the rest of the world. It may be a bit unfair to pose a question to a dream, asking "why," but why should this be so, and what does it mean in practice? Should his native Britain, within the Commonwealth of Nations, privilege its relationship with India over those with Kenya and Australia? Why should a coastline be a consideration in projects of peaceful integration and economic fairness in the first place? Has this consideration not been obsolete since the invention of ships 10,000 years ago - and more so since the invention of modern communication technologies, which make distance irrelevant for many kinds of exchange and interaction?

But does Hann's concept of Eurasia really aim at excluding Australians and Kenyans from the first round of integration (before the Eurasian model is exported to the rest of the world in the way European models were exported previously)? Or who is the real "other"? What is the non-Eurasian entity against which this construct of Eurasia is directed? It seems to be the Tea Party. Apparently, this particular subgroup of North Americans has moved so far from their putatively original Axial Age-inspired communitarian values that they no longer qualify as Eurasians for Hann. Although I share Hann's worries about unrestrained capitalism and the uncritical application of market models to all spheres of public life, I think that, in order to criticize the Tea Party, it is not necessary to construct this huge edifice of unity-in-diversity in Eurasia. Even if it works, that might be overkill. And then, it looks as if this edifice can easily be made to collapse, leaving Tea Party members as laughing bystanders.

For a full-length critique of Hann's theses regarding Eurasia, see my paper on "Civilisations," accessible at http://www .eth.mpg.de/pubs/series_fieldnotes/vol0011.html. The next version of it will appear in a thematic issue on "Rethinking Culture, Area and Comparison" of the Zeitschrift für Ethnologie, planned for 2016.

\section{Peter Skalník}

Department of Politics, University of Hradec Králové, Komárov 81, 53002 Pardubice, Czech Republic (petr.skalnik@uhk.cz; skalnik .petr@gmail.com). 13 V 15

Chris Hann's article aims at promotion of a novel concept of Eurasia. The problem is that this is done in the name of sociocultural anthropology, a discipline that has had very little influence beyond its narrow scope. It therefore sounds not very persuasive, because other disciplines have been much more concerned with the application of the concept. Hann refers to selected historical common denominators and then jumps straight to twentieth-century communism as an allegedly Eurasian phenomenon. References to Goody's writings on various aspects uniting and connecting Europe and Asia are certainly aptly chosen, and so is the use of Polanyi's economic theories, such as embeddedness. But these references make an impression of a tour de force, as if the author is a strong believer in the concept and selects available supporting material. The selectivity of argumentation weakens the argument, and the reader becomes ever more suspicious. Eurasia appears rather as an epitaph about a concept that could have been important if history had evolved otherwise. It is good that Hann added an appendix about political Eurasianism. The political definition of Eurasia actually means that that part of Russia located geographically in Europe is in fact culturally part of Asia. Eurasia, in Hann's conceptualization, still dwells on the priority of Europe because, in effect, we are dealing with Asia's appendix, conventionally called "Europe." Even historically, if we consider the nomads invading Europe, there was just one landmass to be conquered, and Europe has meant for these masses of conquerors just a remaining land to be occupied. They did not need concepts such as Europe and even less so Eurasia. China also did not take Europe as something really existing during the Marco Polo era and did not do so until the nineteenth century, when Europeans temporarily managed to subdue her. The past 40 years of China's emancipation may also contribute to an eventual obsoleteness of Europe as something separate. But Hann does not mention the European Union as an embodiment of Europe as a separate continent and concept. Rather, he seems to be fascinated by the communist attempt at a society without a market. In Hann's understanding, Eurasia is a concept that purports to unite the historical cases of embeddedness and a reduced role for market. However, China's ascent is contrasted with European postcommunism, which lags behind both the western part of Europe and eastern-Asian advances.

"Eurasian mental space," as propounded by Hann, is wishful thinking in the twenty-first century because of the increasing mental and cultural hegemony of eastern Asia, namely, China, which coins the meanings. If Hann wanted to prove that Eurasia really means something relevant for the whole social space between the Atlantic and the Pacific, he would have to be more aggressive in the presentation of his argument. Personally, I would love that anthropology determines the intellectual agenda and public debates, but it cannot succeed in doing so by selecting a Procrustean bed of a concept like Eurasia and filling it with selected pieces of knowledge. Because Hann has been working with the concept of Eurasia for a long time, I would not advise him to remove "Eurasia" from his arsenal of terms but rather encourage him to approach the concept from the emic side before transferring to etic conclusions. Similarly to the concept of "socialism," which he uses throughout his work so faithfully but, to my mind, uncritically, "Eurasia" might come out as a much less scientific term than it appears to Hann. If Eurasia proves really to be more than a chimera of academics, then I would suggest that an anthropological journal such as Current Anthropology is hardly a suitable forum. The readership is limited to people 
who would just be curious to know more about Eurasia in the imagination of academic intellectuals such as the author. But nothing more! An intellectual debate on Eurasia should be broadened beyond the inward-looking discipline of anthropology, which vainly believes in its capacity for revelation. Social scientists, other academics, theologians, politicians, and the general public all have their positions on Eurasia and other oppositions of the contemporary world, however derived from the past. If we admit that China is soon going to lead the world, how shall we work in the concept of Eurasia that takes into account this epoch-making turnover? Why does Europe have to be counted within the concept of Eurasia when it is actually being marginalized? Russia, as an epitome of Eurasia in some conceptualizations, also requires much more consideration. But that is to be done in future writing and speaking about the concept. Hann's article may not have come with valid conclusions, but its usefulness consists in its capacity to open a debate, scientific and beyond, about the content of our times, in which Europe both as a concept and reality increasingly loses its power. Does "Eurasia" take its place? My tentative answer is "hardly."

\section{David Wengrow}

Institute of Archaeology, University College London, 31-34 Gordon Square, London WC1H 0PY, United Kingdom (d.wengrow@ucl.ac .uk). 15 IV 15

Chris Hann's article makes a bold argument for the historical "diversity within unity" of Eurasia. He manages to combine a staggering scale of analysis with analytical clarity and a theoretical vision that extends from the Bronze Age past into the future. Hann's attack on Anglocentrism in contemporary anthropology cuts deep, revealing an "Atlantic bias" in even the most wide-ranging and historically oriented of postcolonial studies. But he gives us far more than critique, building instead on Jack Goody's original conception of how the Eurasian past might be viewed as a complex social totality (a "civilization"), unified in part by its grand heritage of urban life and literacy, but also (and here Karl Polanyi is the key figure) by its shared fund of institutional strategies for limiting the penetration of commercial forces into social life.

An analysis of this breadth will inevitably look odd from certain perspectives. The Middle East is mostly absent (except for the Bronze Age), and the position of sub-Saharan Africa is hardly dealt with - a notable contrast with Goody, who tended to define Eurasia in a relationship of difference with that region. Instead there is an emphasis throughout on shared institutional features of Western Europe and the post-Soviet East, in particular variants of socialism, which are presented as a legacy of the deep past, extending back to the Bronze Age. How contemporary Islam, for example, might fit into this picture remains mostly unclear, and religious var- iants of the "embedded economy" (for which, see Maurer 2005) are little discussed by comparison with broadly secular statedriven forms.

It is stimulating to see social anthropology engaging again with deep history and archaeology, but there is little acknowledgement here of archaeologists' and historians' own extensive engagement with Polanyi's work. Very few, I suspect, would still support the idea of institutionally "embedded" economies in the Bronze and Iron Ages. Or they would at least qualify this as an impression given by elite (literary and pictorial) sources, which rarely match up to the archaeological record in a simple or direct way and often deliberately mask the commercial logic of early state formation that comes through in wider distributions of material culture and related economic documents (it is on this broader point, rather than in relation to the more limited issue of "merchant cultures," that the Sherratt and Sherratt [1991] article warrants further attention, as does the early work of Jonathan Friedman and others [e.g., Ekholm and Friedman 1979] and more recent, fruitful collaborations between economists and ancient historians [e.g., Hudson and Levine 1996]).

Hann emphasizes, throughout, that he is writing a "realist history" (Realgeschichte) for Eurasia. But is there also a provocative - and perhaps risky - dose of "salvation history" (Heilsgeschichte) here, with Childe, Polanyi, and Goody situated as vehicles of redemption? This is a heady theoretical mixture. V. Gordon Childe, as Hann acknowledges, is something of a trickster figure as regards the concept of Eurasia. In fact, a guiding strand in Childe's work is that, with the origins of urban life (c. 3500 BC), Europe and Asia began to diverge in fundamental aspects of social and economic organization, with consequences for the forms of modernity (respectively, liberal-individualist and authoritarian-collectivist) that emerged at later points in their respective histories. Goody, however, has consistently ignored this aspect of Childe's work, recasting him as an early champion for the concept of a "Eurasia" that has been united by cultural exchanges since the Bronze Age.

Yet it was Childe who defined "civilization" in terms of a restricted set of institutional criteria - such as literate bureaucracy, urbanization, commercialism, monumentality, and the hierarchical interdependence of peasants, craft specialists, and governing classes - implying some other (now largely undefined) status for the many Eurasian societies that chose alternative paths through history and continue to do so. Archaeologists have not deal adequately with Childe's legacy in this respect. This article should stimulate us to do so.

\section{Reply}

These rich comments reached me at a special moment: 2 days after the funeral of Sir Jack Goody, widely recognized as the 
last representative of a classical school in social anthropology. I first encountered the concept of Eurasia not in the works of Russian nationalists but in lectures and texts by Goody in the 1970s. My article owes much to his inspiration. But Goody promoted a critical spirit rather than slavish imitation. Gingrich is right to note my criticisms (Hann 2015). Wengrow confirms in his comment that Goody's reading of Gordon Childe distorts the perspective of the great archaeologist. Childe was not inclined to see East and West as deep equivalents, periodically alternating the torch of progress, as in Goody's interpretation. Be that as it may, the primary message of my article is to place Eurasia, rather than Europe, at the center of world history in recent millennia. The outstanding anthropological proponent of this cause has now fallen silent. In responding to my commentators I once again salute Goody's achievements, while noting weaknesses and indicating what I take to be fertile fields for further research that he did not plow himself; this is the better form of homage.

\section{What's in a Name? Long Live Isaarue!}

I knew I was asking for trouble in inviting fellow anthropologists to revisit a term that is nowadays defined differently by more powerful disciplines, not to mention politicians and journalists. I focused on a concept rather than the word but enlarged the scope for confusion by arguing that a Eurasia that had played a vital role in world history could be revived to help humanity address contemporary predicaments. In one article I mixed past and present, positive and normative, realist and imaginative, metageography and substantivist economic anthropology, jeu d'esprit and Heilgeschichte, geopolitics and parochial academic politics. This was a risky undertaking. Considering that most of the commentators on an article explicitly critical of received perceptions of Europe are themselves Europeans, all in all they have let me off quite lightly. They have provided stimulating comments, and I note a general agreement on the desirability of macroregional long-term historical analysis; even occasional misunderstandings may prove instructive.

To begin with the word: I concede that "Eurasia" is less than ideal. The origin of the problem, let it be restated, is the classification of Asia and Europe by the Ancient Greeks. Bošković elaborates on some of the later contingencies that gave rise to Europe as we conceptualize it nowadays, as a continent. Gellner points out that the term "Middle East" is now commonly rejected in favor of "West Asia." But this particular reclassification does not resolve the problem if Europe continues to be regarded as a continent, rather than a large region comparable to West or South Asia. Methodological continentalism is a more insidious obstacle to clear thinking than methodological nationalism, which Gellner thinks we have now overcome ( $\mathrm{I}$ am less confident than he is on this point).

Gingrich and Skalník argue that Eurasia is too prominent and negatively weighted in public discourse to be adapted for our scientific purposes. I find this disappointing, given that many distinguished scholars have applied the nomenclature "Eurasia" to the entire landmass in convincing fashion. Although the name has now been taken up by respected areastudies institutions and journals in ways that differ from those of Jack Goody and William McNeill, to concede defeat on this point seems a cowardly capitulation. At the very least, it behooves us to come up with an alternative scientific name for the unified landmass. For example, we might jumble the letters and call it Isaarue, thus avoiding any confusion with "emic" concepts (where Skalník thinks I should begin). This could not be invoked ideologically, in the ways in which Eurasia is nowadays manipulated to mobilize masses in Russia. So readers who believe that Eurasia carries the moral freight of "fascism" (Gingrich) can opt from this point onward to substitute "Isaarue" for every occurrence of "Eurasia" in this text. But personally I find this unnecessary. Eurasianism, together with postsocialist neo-Eurasianism, which Benovska-Sabkova has no trouble distinguishing from the scientific program of my department at the Max Planck Institute for Social Anthropology, is a phenomenon that the historical social sciences can explain. As I noted, these isms have some features in common with German reactions to the universalism of the French Enlightenment more than two centuries ago, a countermovement that fed into the early history of sociocultural anthropology. I come back to the discipline below.

\section{Historical Institutionalist Economic Anthropology}

My concept of Eurasia is first and foremost a dynamic configuration in world history over millennia. This inevitably gives rise to concerns over boundaries, raised most forcefully by Eriksen. But if the ancestors of the Vikings can nowadays be claimed as Europeans, following the classification of antiquity, I see no insuperable problem in subsuming Evenki and comparable peoples, organized until quite recently primarily through the institutions of kinship rather than states, in a historic Eurasia. My outline is admittedly sketchy and the argumentation selective (Skalník), and I can see why Wengrow detects elements of "salvation history." But it is predicated on a core central territory in the Bronze Age that is essentially undisputed (although, in his critique, Schlee prefers to retain the old German designation Hochkulturgürtel). I argue that this core expands through imperial conquest and other means to embrace the entire landmass by the twentieth century, when the "electoral" and the Marxist-Leninist-Maoist variants of socialism were at their peaks.

Certainly coastal Kenya and Madagascar figured in early global systems. I find the case of Ethiopia even more interesting. But these were not integral over the long term. I should indeed have tried to allocate more space to regions such as India and Southeast Asia, to make this difference clear. The Iberian Peninsula was geographically peripheral, but it has been connected to East Asia by information networks across the belt of agrarian empires for more than two millennia (Kradin) 
and came to exemplify many elements of the core. I acknowledge the role of its peoples in the formation of Latin America, analogous to that of Northern Europeans elsewhere in the world, and the manifold impact of the New World on the Old (Ribeiro). It goes without saying that boundaries of all kinds have been repeatedly broken through technological changes, particularly in recent centuries through revolutions in what Goody termed the means of communication. But these centuries, in which European and American powers dominated these processes, have been intensively studied in numerous disciplines. Many anthropologists teach their discipline and its own history against this backcloth. While quick to condemn crippling Eurocentrism in one optic, anthropology has been slower than other disciplines to overcome it in another. We lag behind historians in broaching the long-term unity of Eurasia (for a new overview by a historian, see Frankopan 2015).

The charge of Eurasiacentrism, formulated most explicitly by Ribeiro, is therefore valid. But I am not claiming that the democracy of Aristotle's era, from which women and slaves were excluded, is the same as the inclusive democracy of modern Greeks. Pattern seeking over long periods at such rarefied levels should not be taken too literally at the level of social groups. Goody's well-known contrast between bridewealth and dowry (Goody and Tambiah 1973) is not invalidated by the fact that bridewealth is also well documented in many Eurasian societies, including some within the core zone. The genealogies of ideologies are more complex than I could explore in this article, and the decoupling of the territorial and socially inclusive aspects of Eurasia has a long history (though not quite as long as Rogers seems to suggest). The phenomenon of selfish utility maximization (homo economicus) and elements of "individualism" in ideology and practice are omnipresent in Eurasia, as perhaps they are in every human community. Conversely, Eriksen asks about economic embeddedness in other world regions, and Pina-Cabral points out that the oikos is not specific to Eurasia. I did not claim that it was; but the oikos debate has a special historiographical status, and the Aristotelian case for self-sufficiency in opposition to priceforming markets captures a transformative moment (see Gudeman and Hann 2015). Pina-Cabral invites me to consider the case of Monica Wilson's Nyakusa in this regard. Despite German and British colonial distortions, I agree that this African society in the 1930s can be classified as embedded in the sense of Polanyi. But what was the scale of the Nyakusa chiefdoms, with their mixed economies and age-village institutions? The challenge is how to retain such communal embeddedness in much more complex forms of society. Schlee's invocation of egalitarian African pastoralists is similarly beside the point. Eurasia matters because it is the "most-extended-in-time project" (Kradin) the world has known in the uncharted waters of bureaucratic institutions and highly differentiated states.

Scholars and ordinary citizens in locations such as southern Tanzania nowadays do not need to glean this basic insight from a Current Anthropology article or from history books. Chinese capital and skills are visible all over Africa. The de- scendants of Wilson's Nyakusa live in countries that do not receive significant aid or commercial investment from neighboring Kenya, or Ethiopia, or Madagascar, or Australia, to mention a few of the non-Eurasian locations introduced by my commentators. In the twenty-first century, an expansive China is increasingly able to displace Euro-American power with new forms of domination, which have significantly different implications for local populations (Lee, forthcoming). Goody's fundamental point is that it becomes easier to make sense of these developments when one starts not from assumptions of the European invention of modernity after Columbus but from the long-term unity of Eurasia.

Contrary to Pina-Cabral, in neither the historical nor the contemporary dimension of my article do I "demonize" market relations. I was inoculated against this particular virus in the 1970s when I compared social life in two distinctive forms of socialist economy. While Hungary was dynamic and offered citizens ample opportunities to better themselves through reliance on a market principle, Poland avoided such institutional reforms. Its population suffered in consequence, such that even basic food supplies were commonly disturbed. As Karl Polanyi knew, no complex society can dispense with the market. In spite of communitarian lapses and rhetorical exaggerations, his approach is still of immense value in analyzing the financialized global capitalism of today (Fraser 2014). The point is that markets must remain embedded in other forms of integration. I do not know enough about the debates among archaeologists and ancient historians to comment on Polanyi's standing in those disciplines. Gareth Dale's assessment (2010:137-187) is more positive than that of Wengrow (though both cite the critical work of Michael Hudson). But when Wengrow writes of a "shared fund of institutional strategies for limiting the penetration of commercial forces into social life" across Eurasia, he captures the essence of my historical argument perfectly. I also agree with him concerning the need to go beyond both Goody and Polanyi in the integration of religion (cosmology) into historical institutionalist analysis. This article barely scratches the surface of this task (Gingrich is right that Axial Age ideas should be engaged more closely).

\section{Europe and Eurasia Today}

To those commentators who point to all the other centers of economic and political action in the world today, I say, Yes, agreed, but it might nonetheless be worthwhile to take a fresh view of long-term histories. By this I mean time frames longer than the past few centuries, still the default position of most anthropologists (when they consider history at all).

When it comes to contemporary dilemmas, I cannot help placing Europe center stage. Skalník's observation on this point is acute. I care about Europe because I am a European myself. Rogers is right to emphasize how my perspective is related to the region of my field research. I have spent several years working in the "other Europe" and am very familiar 
with the syndromes to which Bošković draws attention, as well as current economic plights emphasized by Skalník. Millions of people who live in Europe, as it is defined in textbooks, locate it elsewhere in their imaginations. Some specify the European Union, others the Eurozone or the Schengen zone. (Kradin reports the laconic communication of a frontier guard that "Europe is Schengen.") At all events, the entity that has the positive valence excludes most of Eastern Europe and the Balkans.

The idea that I found to be widespread in socialist times, namely, that Western democracies enjoyed morally superior forms of government and human rights as well as materially superior living conditions, has weakened considerably in Eastern Europe. German officials less corrupt than those one knows at home still win grudging respect from migrants because they are less corrupt than those one has to deal with at home, but it is increasingly obvious that Europe is a deeply divided and compromised region. The Euro was doomed at birth, and it became clear in the first half of 2015 that the powerful states of the north were not prepared to continue practicing solidarity with their economically weak southern neighbors. Meanwhile, the ghosts of the Cold War have reappeared, thanks to the crisis in Ukraine. In other parts of Eastern Europe, too, elites play the Europe card to trump their local rivals and solicit Western help to exclude Russia. Should Europeanist anthropologists refrain from drawing attention to these processes? Pina-Cabral summarizes some of the current iniquities, before concluding that we must nonetheless "hold on fast to the ecumenical ideals of European integration." "Ecumenical" is a fine word of Greek origin. I used to share such ideals myself, since my entire education saturated me in them. But the dominant forces in today's Europe are accentuating divisions rather than working to alleviate them, as we witness in the tragic flow of migrants across the Mediterranean. The most basic reason for looking to Eurasia today is that nothing remains of the ecumenical project of European integration: in political, economic, and sociocultural terms alike, it has been aborted.

\section{A Restatement}

Few members of the Max Planck Society can expect to receive the same close attention from a co-Director that Schlee has paid to my work in recent years. Some readers will be puzzled, however, especially by the opening paragraphs of his commentary. The concepts of moral economy and civilization are central to my current European Research Council (ERC) project. ${ }^{14}$ But they are not salient in this particular article, in which moral economy is not even mentioned. Schlee might have done better to scrutinize chronologically earlier formu-

14. See the acknowledgements above. Further information about REALEURASIA is available at the home page of the Max Planck Institute for Social Anthropology. See also the project blog: http://www .eth.mpg.de/3557160/blog. lations of Eurasia, which, as Benovska-Sabkova notes, I have been using since at least 2003. It is a theoretical and empirical framing concept: my department's research, including my own, proceeds concretely at other levels, primarily the ethnographic. Of course, even in reiterations of the frame one tries not to repeat oneself too blatantly and hopes to advance understanding from time to time. Schlee juxtaposes a review article published in an anthropological journal in 2008 with a 2014 contribution to a British magazine of radical dissent in a thematic issue devoted to "austerity." Obviously, the context and political agenda of the latter piece (more in the genre of "outreach," as counseled by Skalník) were somewhat different from those of earlier scholarly papers. But, although I am given credit for doing so, I have not altered my usage of Eurasia in any substantive way over the years. Some formulations in the present article are prompted by what was happening in the world in 2014-2015, but it also attempts to step back and place these crises in a world-historical perspective, because it is intended as a cornerstone of the new ERC research.

At the risk of boring some patient readers and increasing the frustration of others, let me offer another simple restatement of my position concerning the unity of Eurasia. It is a banal fact that the whole world acknowledges German unity since 1990. Our Max Planck Institute in Halle is a product of the (re-)unification process. Yet anyone who has lived in Halle in recent decades and gotten to know locally born neighbors is aware that, compared to West Germans, East Germans by and large think and behave in some distinctive ways. There is, in short, a rather basic diversity within German unity (I leave aside the persistence of indigenous minorities such as the Slavic Sorbs, the Danes of Schleswig-Holstein, and the much larger populations of recent immigrants). A mere 4 or 5 generations before the socialist East German state, the very idea of German unity on the basis of a common Schicksalgemeinschaft was by no means taken for granted, in any stratum of the fragmented population of German speakers. The boundary of today's federal state does not coincide with linguistic boundaries. We might describe these historical processes as highly contingent; of course, the Germanic tribes are not unusual in this respect.

Today's German elites, indeed most of the population, are very much in favor of European integration. The project of unity in diversity at this new level has served Germans well for many decades, but many believe in it for reasons that have nothing to do with material advantage and command respect. I argue that this project has failed. European-level institutions lack basic legitimacy. More and more Germans are losing their enthusiasm for integration as a result of recent crises, of which they see themselves as victims, since they are asked to pay the bills. In Germany, as elsewhere in Europe, an aggressive, intolerant, inward-looking populism is the main political consequence of these trends. While some observers call for a deepening of European institutions, other scholarly analysts counsel a return to the institutions of the nation-state in order to preserve democratic legitimation. My position is 
different (Hann 2014a). I argue that, given global geopolitical constellations, it now makes more sense to aim at new forms of integration at the level of Eurasia. If this sometimes comes out sounding alarmist and shrill, this is because I do not think such integration is happening anyway. The "pragmatic" stance of Gingrich would be an attractive alternative; but unfortunately, the present European Union ignores ASEAN and portrays the Russian-led Eurasian Economic Union as an enemy in order to justify forging even closer links to NAFTA and enhancing free trade in the Atlantic region.

At the Eurasian level, too, the basic criteria of unity in diversity are met, once one extends the time frame appropriately. It goes without saying that the diversity is greater than in the case of Germany or Europe, in terms of languages, religions, kinship, cuisine, and all the other things routinely investigated by anthropologists. But these are details. Just as the European Commission generously supports programs to promote European identity, based in an allegedly shared history, so a future Eurasian Commission might provide the funding to turn the potential that is there from Mesopotamia onward into a subjectively convincing reality. I doubt that such an entity could ever come about - even Europe is much too big to comprise a Schicksalgemeinschaft_-but it could at least form a frame for new pragmatic forms of constitutional governance while the emotional identifications persist at lower levels. Eriksen and Gellner will be pleased to hear that the impulse behind this utopian conceit on my part comes not from philosophical speculation but from concrete ethnographic experiences in China, where social security entitlements have been progressively extended to include the entire vast rural population. These moves are compelling evidence, for me, of a base of values across the landmass that are shared in very different forms in Japan, Kazakhstan, and Greece (to take the trio specified by Eriksen) but not globally-certainly not in the United States. ${ }^{15}$ Why, then, should it be utopian, in the sense of foolishly implausible, to postulate new forms of polity, economy, and society on the basis of this evolved Eurasian bedrock of unity in diversity?

15. The Tea Party may be a small minority, and of course one must distinguish its rhetoric from the realities of state-society relations in the United States. But at the time of writing, a Republican contender for the presidency (Ben Carson, a retired black neurosurgeon) compares Obamacare to slavery. In the apocalyptic scenario, to which I made only brief allusion in the article, these principles of the New World displace the legacy of the Old even in its heartlands, to become dominant globally. In the early twenty-first century, these free-market, minimal-state ideologies are especially salient in the English-speaking world, where they combine in contradictory ways with new manifestations of nationalism. It was not always thus: in the middle decades of the past century, between the New Deal and the Great Society program of the 1960s, when the British welfare state was put in place, both the United States and the United Kingdom were extending the frontiers of the Eurasian agenda.

\section{Anthropology}

In this forum it is appropriate to conclude by discussing the implications of my article for the scope, theory, and practice of anthropology. Pina-Cabral counters my jibes concerning the dominance of the Anglosphere by pointing out that some influential English-language journals nowadays publish contributions from other traditions around the world. This seems to me still to be quite limited. To the extent that it takes place, it still tends to reinforce the current standards (or fashions) of the Anglosphere and the position of scholars trained in it (even if they later work elsewhere). I shall always find it extraordinary that, every November, in universities around the world, normal anthropology classes are suspended because so many staff feel obliged to make the pilgrimage to the American Anthropological Association meetings.

I am encouraged by the fact that most commentators, no matter how critical of my concept of Eurasia, agree that sociocultural anthropologists should devote more energy to the analysis of macro-level historical change. (I did not dare write "evolution.") We have not contributed much in recent decades to the world-systems analysis commended by Kradin and Wengrow. For Schlee, culture remains the key term, but I avoided this in my article. I have the same suspicion of the substantive "culture" (and only slightly more tolerance of the adjectival form) that Pina-Cabral has of the substantive form "Eurasia” (see Hann 2000). Contrary to Schlee's assertions, I have never postulated Eurasia as a "cultural unity." Instead, I prefer to use "civilizations" in the plural and to analyze them dynamically and comparatively, in terms of their internal hierarchies and external relations with each other, with reference to structural factors, institutions, and social relations. Let us hope that the forthcoming thematic issue of the Zeitschrift für Ethnologie will revive the cause of "cultural classification" without falling back into the "musty ... anthropology of world regions" derided by Rogers. Perhaps this issue will resolve the chimera of "culture" once and for all. Personally, I shall be particularly appreciative if, while drawing out the important contributions made by the German ethnologists of earlier generations, authors manage to link them in new ways to the better-known contributions of scholars such as Weber and Marx. ${ }^{16}$

The platform created so far in my department in Halle is a complex synthesis. The Eurasian agenda of Jack Goody is the solid foundation. A long essay published in the month of his passing provides an excellent introduction to his mature work, with its emphasis on the unity of the landmass (Goody 2015). Goody's arguments are rooted in the emergence of plow agriculture, the distribution of ores, and urban differentiation. He concentrates on kinship and domestic institu-

16. Although I am a member of this association that publishes this journal, I have not been able to glean any information about the forthcoming thematic issue. 
tions, luxury goods, and communication. The Silk Roads (terrestrial and maritime) of the past can be supplemented with analysis of the pipeline politics of the present (Rogers). Goody's vision can also be consolidated through Polanyian investigations of the embeddedness of the economy in particular forms of polity and Weberian research into religion and ethics (including the Wirtschaftsethik) and the legitimacy of complex forms of Herrschaft. The concept of civilization is a key element in operationalizing this agenda. We use it in the dynamic sense of Johann Arnason, and behind him Durkheim and Mauss (see Arnason and Hann, forthcoming). Much more work must be done here. The current ERC project specifies the civilizational diversity of historical Eurasia with reference to the world religions. But at the edges, and in plentiful nooks and crannies of the heartlands, as noted by several commentators, these "great traditions" have interacted with very different forms of civilization and continue to do so. Traditionally, anthropologists have specialized in the nomads and the hill tribes, while the civilized centers have been the focus of other disciplines and area-studies specialists. Gellner commends James Scott's work on Zomia and Pina-Cabral that of Christopher Beckwith on Central Eurasia. These immensely stimulating authors complicate and complement my model, but I do not see them as refuting it (the latter's perspective resembles that of Arnason's "inner Eurasia," which I noted).

To document the paths not followed in history will always be a favorite preoccupation of anthropologists; a penchant to romanticize others, to celebrate anarchists rather than bureaucrats, is a part of our disciplinary identity. But analyzing economic, political, and religious differences between territories, societies, or civilizations is not inherently problematic normatively. It must be possible to argue that, in recent centuries, France has played a more significant role in world history than Uttar Pradesh (Bošković, criticizing Lewis and Wigen 1997). More generally, it must also be part of the remit of anthropologists, in the frame of a comparative historical social science, to do justice to those distinctive forms of civilization that turned out to be monumentally powerful in shaping our modern world. Here my sympathies are very much with Goody and both Gellners (i.e., the late Ernest as well as David).

In their investigations of particular civilizations and civilizational encounters, as Gingrich emphasizes, historical anthropologists must work closely with specialists in several other disciplines. This particular exercise had a different purpose, at a more rarefied level, but the dialogues with archaeology and global history are always vital.

-Chris Hann

\section{References Cited}

Arnason, Johann P. 2003. Civilizations in dispute: historical questions and theoretical conditions. Leiden: Brill.

- 2015. State formation and empire building, 500-1500. In Expanding webs of exchange and conflict, 500 CE-1500 CE, vol. 5 of The Cambridge World History. Benjamin Z. Kedar and Merry E. Wiesner-Hanks, eds. Pp. 483-512. Cambridge: Cambridge University Press.
Arnason, Johann P., Shmuel Eisenstadt, and Björn Wittrok, eds. 2005. Axial civilizations and world history. Leiden: Brill.

Arnason, Johann P., and Chris Hann, eds. Forthcoming. Anthropology and civilizational analysis: Eurasian encounters.

Barfield, Thomas J. 1989. The perilous frontier: nomadic empires and China, $221 B C$ to $A D$ 1757. Oxford: Blackwell.

Beckwith, Christopher I. 2011. Empires of the Silk Road: a history of central Eurasia from the Bronze Age to the present. Princeton, NJ: Princeton University Press. [JPdC]

Bellah, Robert N., and Hans Joas, eds. 2012. The Axial Age and its consequences. Cambridge, MA: Harvard University Press.

Bernstein, Anya. 2013. Religious bodies politic: rituals of sovereignty in Buryat Buddhism. Chicago: University of Chicago Press.

Bicilli, Petâr. 2004 (1927). Dva lika na evrazijstvoto [Two images of the Eurasianism]. In Natsija i kultura. Pp. 102-125. Sofia: Iztok-Zapad. [MB-S]

Block, Fred L., and Margaret R. Somers. 2014. The power of market fundamentalism: Karl Polanyi's critique. Cambridge, MA: Harvard University Press.

Bošković, Aleksandar. 2003. Michel Leiris: ethnologist in search of meanings. Anthropos 98(2):526-529. [AB]

- 2010. We are all indigenous now: culture versus Nature in representations of the Balkans. In Culture wars: context, models and anthropologists' accounts. Deborah James, Evelyn Plaice, and Christina Toren, eds. Pp. 86-96. New York: Berghahn. [AB]

2014. Antropološke perspektive. Belgrade: Institute of Social Sciences. $[\mathrm{AB}]$

Bowersock, G. W. 2013. A different turning point for mankind. New York Review of Books, May 9. http://www.nybooks.com/articles/archives/2013 /may/09/different-turning-point-mankind/. [GS]

Chakrabarty, Dipesh. 2000. Provincializing Europe: postcolonial thought and historical difference. Princeton, NJ: Princeton University Press.

Chari, Sharad, and Katherine Verdery. 2009. Thinking between the posts: postsocialism, postcolonialism, and ethnography after the end of the Cold War. Comparative Studies in Society and History 51(1):6-34. [DR]

Chase-Dunn, Christopher, and Thomas D. Hall. 1997. Rise and demise: comparing world-systems. Boulder, CO: Westview. [NK]

Chase-Dunn, Christopher, Thomas D. Hall, Richard Niemeyer, Alexis Alvarez, Hiroko Inoue, Kirk Lawrence, and Anders Carlson. 2010. Middlemen and marcher states in Central Asia and East/West empire synchrony. Social Evolution and History 9(1):52-79. [NK]

Childe, V. Gordon. 1942. What happened in history. Harmondsworth: Penguin.

Dale, Gareth. 2010. Karl Polanyi: the limits of the market. Cambridge: Polity. Dalton, George. 1968. Introduction. In Primitive, archaic and modern economies: essays of Karl Polanvi. George Dalton, ed. Pp. ix-liv. New York: Anchor. Darwin, John. 2007. After Tamerlane: the global history of empire since 1405. London: Allen Lane.

Davis, John. 1987. Libyan politics: tribe and revolution. London: Tauris.

Diamond, Jared. 1997. Guns, germs and steel: a short history of everybody for the last 13,000 years. London: Norton.

Dussel, Enrique. 1993. Europa, modernidad y Eurocentrismo. In La colonialidad del saber: Eurocentrismo y ciencias sociales. Perspectivas latinoamericanas. Edgardo Lander, ed. Pp. 41-53. Buenos Aires: CLACSO (Consejo Latinoamericano de Ciencias Sociales). [GLR]

Eisenstadt, Shmuel, ed. 2002. Multiple modernities. New Brunswick, NJ: Transaction.

Ekholm, Kajsa, and Jonathan Friedman. 1979. "Capital" imperialism and exploitation in ancient world systems. In Power and propaganda: a symposium on ancient empires. Mogens Trolle Larsen, ed. Pp. 41-58. Copenhagen: Akademisk Forlag. [DW]

Eriksen, Thomas Hylland, ed. 2003. Globalisation: studies in anthropology. London: Pluto.

. 2014. Globalization. The key concepts. 2nd edition. London: Bloomsbury. [Florovskii, Georgii, Petr Savickii, Petr Suvchinskii, and Nikolai Trubetzkoy]. 1921. Ishod k Vostoku: predchuvstvija i sovershenija. Utverzhdenija evrazijcev. [Turn to the East: premonitions and deeds. The statements of Eurasianists], vol. 1. Sofia: Rossijsko-bolgarskoe knigoizdatel'stvo. [MB-S]

Frank, Andre Gunder. 1998. ReOrient: global economy in the Asian age. Berkeley: University of California Press.

Frankopan, Peter. 2015. The Silk Roads: a new history of the world. London: Bloomsbury.

Fraser, Nancy. 2014. Can society be commodities all the way down? postPolanyian reflections on capitalist crisis. Economv and Society 43(4):541-558. 
Friedman, Jonathan. 2012. The dialectic of cosmopolitanization and indigenization in the contemporary world system: contradictory configurations of class and structure. In The scope of anthropology: Maurice Godelier's work in context. Laurent Douset and Serge Tcherkézoff, eds. Pp. 212-245. New York: Berghahn.

Furtado, Celso. 2007 (1959). A formação econômica do Brasil. São Paulo: Companhia das Letras. [GLR]

Gellner, David N. 2012. Uncomfortable antinomies: going beyond methodological nationalism in social and cultural anthropology. In Beyond meth odological nationalism: research methodologies for cross-border studies. Anna Amelina, Devrimsel D. Nergiz, Thomas Faist, and Nina Glick Schiller, eds. Pp. 111-128. New York: Routledge. [DNG]

, ed. 2013. Borderland lives in northern South Asia. Durham, NC Duke University Press. [DNG]

Gellner, Ernest. 1981. Muslim society. Cambridge: Cambridge University Press.

Gingrich, Andre. 2010. Transitions: notes on sociocultural anthropology's present and its transnational potential. American Anthropologist 112 (4):552-562. [DNG]

Gingrich, Andre, and Christina Lutter, eds. 2015. Visions of community: comparative approaches to medieval forms of identity in Europe and Asia Special issue, History and Anthropology 26(1). [AG]

Goody, Jack. 1976. Production and reproduction: a comparative study of the domestic domain. Cambridge: Cambridge University Press.

. 1977. The domestication of the savage mind. Cambridge: Cambridge University Press.

. 1982. Cooking, cuisine and class: a study in comparative sociology. Cambridge: Cambridge University Press.

- 1996. The East in the West. Cambridge: Cambridge University Press.

- 2003. Sorcery and socialism. In Distinct inheritances: property, family and community in a changing Europe. Hannes Grandits and Patrick Heady, eds. Pp. 391-406. Münster: LIT.

- 2004. Capitalism and modernity: the great debate. Cambridge: Polity. 2006a. Gordon Childe, the urban revolution, and the haute cuisine: an anthropo-archaeological view of modern history. Comparative Studie in Society and History 48(3):503-519.

. 2006b. The theft of history. Cambridge: Cambridge University Press. 2010. The Eurasian miracle. Cambridge: Polity.

- 2015. Asia and Europe. History and Anthropology 26(3):263-307.

Goody, Jack, and S. J. Tambiah. 1973. Bridewealth and dowry. Cambridge: Cambridge University Press.

Gregory, Chris A. 1997. Savage money: the anthropology and politics of commodity exchange. Amsterdam: Harwood.

Gudeman, Stephen, and Chris Hann. 2015. Introduction: self-sufficiency as reality and as myth. In Oikos and market: explorations in self-sufficiency after socialism. Stephen Gudeman and Chris Hann, eds. Pp. 1-23. New York: Berghahn.

Hann, Chris. 2000. All "Kulturvölker" now? social anthropological reflections on the German-American tradition. In Anthropology beyond culture. Richard G. Fox and Barbara J. King, eds. Pp. 259-276. Oxford: Berg.

. 2003. The anthropology of Eurasia in Eurasia. Working Paper 57. Halle/Salle: Max Planck Institute for Social Anthropology. http://www.eth .mpg.de/pubs/wps/pdf/mpi-eth-working-paper-0057.pdf. [MB-S]

2005. Introduction. In One discipline, four wavs: British, German

French, and American anthropology. Fredrik Barth, Andre Gingrich, Rober Parkin, and Sydel Silverman, eds. Chicago: University of Chicago Press. [JPdC]

_. 2006. "Not the horse we wanted!" postsocialism, neoliberalism, and Eurasia. Berlin: LIT.

. 2008. Reproduction and inheritance: Goody revisited. Annual Review of Anthropology 17:145-158. [GS]

. 2012. Europe in Eurasia. In A companion to the anthropology of Europe. Ullrich Kockel, Máiréad Nic Craith, and Jonas Frykman, eds. Pp. 88-102. Oxford: Blackwell.

2014a. After the Euro, the Avra. Soundings 56:123-136; republished in Eurozine, May 9. http://www.eurozine.com/articles/2014-05-09-hann -en.html.

- 2014b. Towards a maximally inclusive concept of Eurasia. Working Paper 157. Halle/Salle: Max Planck Institute for Social Anthropology.http:// www.eth.mpg.de/pubs/wps/pdf/mpi-eth-working-paper-0157. [MB-S]

. 2015. Goody, Polanyi and Eurasia: an unfinished project in comparative historical economic anthropology. History and Anthropology 26 (3):308-320.

Hann, Chris, and Keith Hart. 2011. Economic anthropology: history, ethnography, critique. Cambridge: Polity.
Hart, Keith. 1986. Heads or tails? the two sides of the coin. Man, n.s., 21 (3):637-656.

2002. World society as an old regime. In Elite cultures: anthropological perspectives. Cris Shore and Stephen Nugent, eds. Pp. 22-36. London: Routledge.

Harvey, David. 2005. A brief history of neoliberalism. Oxford: Oxford University Press.

Hickman, Jacob. 2013. To Zomia or not to Zomia. Savage Minds (blog). Published February 4. http://savageminds.org/2013/02/04/to-zomia-or-not -to-zomia/. [DNG]

Hodgson, Marshall G. S. 1974. The venture of Islam. Chicago: University of Chicago Press.

Holmes, Douglas. 2000. Integral Europe: fast-capitalism, multiculturalism, neofascism. Princeton, NJ: Princeton University Press.

Hudson, Michael, and Baruch Levine, eds. 1996. Privatization in the ancient Near East and classical world. Peabody Museum Bulletin 5. Cambridge, MA: Peabody Museum of Archaeology and Ethnology. [DW]

Humphrey, Caroline. 2002. 'Eurasia,' ideology and the political imagination in provincial Russia. In Postsocialism: ideals, ideologies and practices in Eurasia. Chris Hann, ed. Pp. 258-276. London: Routledge.

Hung, Ho-fun. 2009. America's head servant? New Left Review 60:1-25.

Huntington, Samuel. 1996. The clash of civilizations and the remaking of world order. New York: Simon \& Schuster.

Jaspers, Karl. 1948. The Axial Age of human history: a base for the unity of mankind. Commentary 6(5):430-435.

Kalb, Don, and Gábor Halmai, eds. 2011. Headlines of nation, subtexts of class: working-class populism and the return of the repressed in neoliberal Europe. New York: Berghahn.

Khazanov, Anatoly. 1984. Nomads and the outside world. Cambridge: Cambridge University Press.

Kradin, Nikolay. 2014. Nomads of Inner Asia in transition. Moscow: Krasand. [NK]

Krasner, Stephen D. 2011. State, power, anarchism: a discussion of The Art of Not Being Governed: an anarchist history of upland Southeast Asia. Perspectives on Politics 9(1):79-83. [DNG]

Laruelle, Marlène. 2004. The two faces of contemporary Eurasianism: an imperial version of Russian nationalism. Nationalities Papers 32(1):115136. [MB-S]

- 2007. The Orient in Russian thought at the turn of the century. In Russia between East and West: scholarly debates on Eurasianism. Dmitry Shlapentokh, ed. Pp. 9-38. Leiden: Brill. [MB-S]

. 2008. Russian Eurasianism: an ideology of empire. Washington, DC: Woodrow Wilson Center Press.

- 2009. Pereosmislenie imperii v postsovetskom prostranstve: novaja evrazijskaja ideologija [Rethinking empire in the post-Soviet space: the new Eurasian ideology]. Форум новейшей восточноевропейской истории и культуры [Forum noveishei vostochnoevropeiskoi istorii i kul'tury] 6(1): 78-92. [MB-S]

Lee, Ching Kwan. Forthcoming. Varieties of capital, fractures of labor: a comparative ethnography of precarization on the Zambian Copperbelt. In Regular and precarious labor in modern industrial settings. Jonathan Parry and Chris Hann, eds. New York: Berghahn.

Leiris, Michel. 1996. Miroir de l'Afrique. Édition établie, présentée et annotée par Jean Jamin, avec la collaboration de Jacques Mercier pour les textes ayant trait à l'Ethiopie. Paris: Gallimard. [AB]

Lewis, Martin W., and Kären Wigen. 1997. The myth of continents: a critique of metageography. Berkeley: University of California Press.

Lindstrom, Nicole. 2015. Whither diversity of post-socialist welfare capitalist cultures? crisis and change in Estonia and Slovenia. European Journal of Sociology 56:119-139.

Linebaugh, Peter, and Marcus Rediker. 2000. The many-headed hydra: sailors, slaves, commoners and the hidden history of the revolutionary Atlantic. Boston: Beacon. [GLR]

Maurer, Bill. 2005. Mutual life: Islamic banking, alternative currencies, lateral reason. Princeton, NJ: Princeton University Press. [DW]

McNeill, William H. 1963. The rise of the West. Chicago: University of Chicago Press.

Michaud, Jean. 2010. Editorial-Zomia and beyond. Lournal of Global History 5:187-214. [DNG]

Mintz, Sidney. 1985. Sweetness and power: the place of sugar in modern history. Harmondsworth: Penguin. [GLR]

Mirowski, Philip. 2014. Never let a serious crisis go to waste: how neoliberalism survived the financial meltdown. London: Verso. 
Morris, Ian. 2010. Why the West rules - for now: the patterns of history, and what they reveal about the future. New York: Farrar, Straus and Giroux.

Morse, Richard M. 1988. O espelho de Próspero: cultura e idéias nas Américas. Paulo Neves, trans. São Paulo: Companhia das Letras. [AB]

Piketty, Thomas. 2014. Capital in the twenty-first century. Cambridge, MA: Harvard University Press. [JPdC]

Pina-Cabral, João de. 1989a. L'héritage de Maine: repenser les catégories descriptives dans l'étude de la famille en Europe. Ethnologie Française, n.s. 19:329-340. [JPdC]

. 1989b. The Mediterranean as a category of regional comparison: a critical approach. Current Anthropology 30(3):399-406. [JPdC]

- 2014. Lusotopy as ecumene. In Anthropology now and next: essays in honor of Ulf Hannerz. Thomas Hylland Eriksen, Christina Garton, and Shalini Randeria, eds. Pp. 241-263. London: Berghahn. [JPdC]

Polanyi, Karl. 1944. The great transformation: the political and economic origins of our time. Boston: Beacon.

. 1957. Aristotle discovers the economy. In Trade and market in early empire: economies in history and theory. Karl Polanyi, Conrad Arensberg, and Harry Pearson, eds. Pp. 64-94. New York: Free Press.

Pomeranz, Kenneth. 2000. The great divergence: China, Europe and the making of the modern world economy. Princeton, NJ: Princeton University Press.

Rahmstorf, Lorenz. 2012. Control mechanisms in Mesopotamia, the Indus Valley, the Aegean and Central Europe, c. 2600-2000 BC, and the question of social power in early complex societies. In Beyond elites: alter natives to hierarchical systems in modelling social formations. Tobias L. Kienlin, ed. Universitätsforschungen zur prähistorischen Archäologie 215. Pp. 311-326. Bonn: Habelt.

Ribeiro, Gustavo Lins. 2003. Postimperialismo: cultura y política en el mundo contemporáneo. Barcelona: Gedisa. [GLR]

— 2014a. Outras globalizações: cosmopolíticas pós-imperialistas. Rio de Janeiro: Editora da Universidade do Estado do Rio de Janeiro. [GLR]

- 2014b. World anthropologies: anthropological cosmopolitanisms and cosmopolitics. Annual Review of Anthropology 43:483-498. [GLR]

Ribeiro, Gustavo Lins, and Arturo Escobar, eds. 2006. World anthropologies: disciplinary transformations within systems of power. Oxford: Berg. [GLR]

Ricoeur, Paul. 1986. Lectures on ideology and utopia. New York: Columbia University Press. [GLR]

Rogers, Douglas. 2010. Postsocialisms unbound: connections, critiques, comparisons. Slavic Review 69(1):1-15. [DR]

Ruggie, John. 1982. International regimes, transactions, and change: embedded liberalism in the postwar economic order. International Organization 36:379-415.

Scott, James C. 2009. The art of not being governed: an anarchist history of upland Southeast Asia. New Haven, CT: Yale University Press. [DNG]

Schlanger, Nathan. 2006. Introduction. Technological commitments: Marcel Mauss and the study of techniques in the French social sciences. In Techniques, technology and civilization/Marcel Mauss. Nathan Schlanger, ed. New York: Berghahn.

Sherratt, Andrew, and Susan Sherratt. 1991. From luxuries to commodities: the nature of Mediterranean Bronze Age trading systems. In Bronze Age trade in the Mediterranean. Noel H. Gale, ed. Studies in Mediterranean Archaeology 90. Pp. 351-386. Jonsered: Åström.

Shneiderman, Sara. 2010. Are the Central Himalayas in Zomia? some scholarly and political considerations across time and space. Iournal of Global History 5:289-312. [DNG]

Shnirelman, Viktor. 1996. Evrazijskaja ideja i teorija kul'tury. Etnograficheskoe obozrenie 4:3-16. [MB-S]

- 2006. Evrazijcy i evrei [Eurasionists and Jews]. Skepsis. http://scepsis .net/library/id_952.html (accessed May 30, 2013). [MB-S]

Snyder, Timothy. 2014. Europe and Ukraine: past and future. Eurozine, April 16. http://www.eurozine.com/articles/2014-04-16-snyder-en.html.

Streeck, Wolfgang. 2014. Buying time: the delayed crisis of democratic capitalism. London: Verso.

Supiot, Alain. 2008. L'inscription territorial des lois. Esprit 349:151-170.

Taagepera, Rene. 1978. Size and duration of empires: systematics of size. Social Science Research 7:108-127. [NK]

Teggart, Frederick J. 1939. Rome and China: a study of correlation in historical events. Berkeley: University of California Press. [NK]
Thompson, E[dward] P[almer] 1964 (1963). The making of the English working class. New York: Pantheon. [GLR]

Toynbee, Arnold J. 1934-1961. A study of history. 12 vols. London and Oxford: Oxford University Press. [AB]

1954. 'Asia' and 'Europe': facts and fantasies. In A study of history, vol. 8, Pp. 708-729. London: Oxford University Press. [AB]

Trubetzkoy, Nikolai. 1922. Russkaja problema [The Russian problem]. In $\mathrm{Na}$ putiah. Utverzhdenie evrazijcev. [On the road. Statements of the Eurasianists], vol. 2. Berlin: Gelikon. [MB-S]

Turchin, Petr. 2009. A theory for formation of large empires. Lournal of Global History 4:191-217. [NK]

Tylor, Edward B. 1871. Primitive culture: researches into the development of mythology, philosophy, religion, language, art, and custom. 2 vols. London: J. Murray. $[\mathrm{AB}]$

Umland, Andreas. 2008: Postsovetskie pravoekstremistkie kontrelity i ih vlijanie v sovremennoj Rossii [The post-Soviet right-extremist counter elites and their influence in contemporary Russia]. Neprikosnovennyj zapas, no. 1. http://www.intelros.ru/readroom/nz/nz_57/2286-postsovetskie -pravojekstremistskie.html (accessed June 1, 2013). [MB-S]

. 2009. Rasscvet russkogo ul'tranacionalizma i stanovlenie soobshschestva ego issledovatelej [The bloom of Russian ultra-nationalism and the establishment of its researchers]. Форум новейшей восточноевропейской истории и культуры [Forum noveishei vostochnoevropeiskoi istorii i kul'tury] 6(1):5-38. [MB-S]

Van Schendel, Willem. 2002. Geographies of knowing, geographies of ignorance: jumping scale in Southeast Asia. Environment and Planning D: Society and Space 20:647-668. [DNG]

Verdery, Katherine. 1996. What was socialism and what comes next? Princeton, NJ: Princeton University Press.

Vries, Peer. 2009. Global history. Special issue of Österreichische Zeitschrift für Geschichtswissenschaften 20(2):5-21.

Wallerstein, Immanuel. 1974. The modern world system. New York: Academic Press.

Warman, Arturo. 1988. La historia de un bastardo: maiz y capitalismo. Mexico: Fondo de Cultura Económica-UNAM. [GLR]

Wengrow, David. 1999. The intellectual adventure of Henri Frankfort: a missing chapter in the history of archaeological thought. American Journal of Archaeology 103(4):597-613.

Whitfield, Peter. 1994. The image of the world: 20 centuries of world maps. London: British Library. [AB]

Wiederkehr, Stefan. 2007. Die eurasische Bewegung: Wissenschaft und Politik in der russischen Emigration der Zwischenkriegszeit und im postsowjetischen Russland. Köln: Böhlau.

—. 2012. Vosprijatie trudov L. N. Gumileva v pozdnesovetskij i postsovetskij periody: intelligentsija $\mathrm{v}$ Rossii v poiskah orientirov [The perception of works by L. N. Gumilev in the late Soviet and post-Soviet periods: intelligentsia in Russia in search of orientation]. Форум новейшей восточноевропейской истории и культуры, русское издание [Forum noveishei vostochnoevropeiskoi istorii i kul'tury] 9(1):7-20. [MB-S]

n.d. Eurasien: http://eeo.uni-klu.ac.at/index.php?title=Eurasien (accessed October 12, 2014).

Wilkinson, Toby C., Susan Sherratt, and John Bennet, eds. 2011. Interweaving worlds: system interactions in Eurasia 7 th to the 1st millennia BC. Oxford: Oxbow.

Wilson, Monica. 1963 (1951). Good company: a study of Nyakyusa agevillages. Boston: Beacon. [JPdC]

Wimmer, Andreas, and Nina Glick Schiller. 2002. Methodological nationalism and beyond: nation-state building, migration and the social sciences. Global Networks 2(4):301-334. [DNG]

Wintle, Michael. 2002. Europe on parade: the First World War and the changing visual representations of the continent in the twentieth century. In Ideas of Europe since 1914: the legacy of the first World War. Menno Spiering and Michael Wintle, eds. Pp. 105-129. Basingstoke: Palgrave Macmillan. [AB]

Wolf, Eric R. 1982. Europe and the people without history. Berkeley: University of California Press.

Wouters, Jelle J. P. 2012. Keeping the hill tribes at bay: a critique from India's Northeast of James C. Scott's paradigm of state evasion. European Bulletin of Himalayan Research 39:41-65. [DNG] 